\title{
Driving Forces of the Swiss Output Gap
}

\author{
Stefan LeIST ${ }^{a}$
}

JEL-Classification: C11, C51, E32, F41

Keywords: DSGE models; output gap; natural level of output; small open economy; business cycle; recessions

\section{Introduction}

Are recessions mainly driven by foreign output shocks, or are they due to interest rate shocks? In short, what drives the output gap? The conduct of fiscal and monetary policy is fundamentally related to the output gap (e.g. GALí, 2008). For the proper conduct of monetary and fiscal policy, knowing the causes of fluctuations in the output gap is vital. In contrast to agnostic statistical approaches to extract business cycles, the model-based approach followed in this paper permits analyzing periods of recession and their respective driving forces. The introductory questions are especially important in today's world, as the last recession is argued to be different from the previous ones, and this difference can only be revealed by a model-based approach.

The literature typically relies on statistical procedures such as the HP-filter to extract the business cycle or uses the production function approach (STALDER, 2002). The latter estimates the "full input utilization" output level, but it neglects cyclical variations of potential output (NeIss and NeLson, 2005). Furthermore, agnostic statistical procedures do not enable the researcher to analyze the driving forces of the output gap. Another strand of the literature relies on unobserved components models. However, none of these approaches provide an estimate of the flexible price output gap, which is the most appropriate concept (McCALLuM

a State Secretariat of Economic Affairs (SECO), Holzikofenweg 36, CH-3003 Bern, Switzerland. Email: stefan.leist@seco.admin.ch. The views and opinions expressed in this paper are solely those of the author and are not necessarily those of the State Secretariat for Economic Affairs. The paper was written while the author was at the University of Bern, Switzerland. I thank Gregor Bäurle, Fabrice Collard, Harris Dellas, Behzad Diba, Sarah Lein, Klaus Neusser, Heiner Mikosch, anonymous referees as well as participants at the Young Swiss Economists Meeting 2012 and the SSES Annual Meeting 2012 for valuable comments. All remaining errors are mine. 
and Nelson, 1999; McCallum, 2001; Woodford, 2003; Galí, 2008). This approach ensures that efficient fluctuations of output do not affect the output gap measure, which is consistent with Kydland and Prescott (1982). Therefore, researchers recently relied on a model-based approach and used New Keynesian DSGE models to obtain estimates of the output gap. However, most of these models are applied to closed economies (e.g., Andres, Lopez-Salido, and Nelson, 2005; Neiss and Nelson, 2005; Edge, Kiley, and Laforte, 2008; Justiniano and Primiceri, 2008). Some of the literature on the estimation of small open economy models assumes that monetary policy reacts to an output gap measure, but flexible price output is specified as being exclusively driven by foreign output (Lubik and Schorfheide, 2007; Del Negro and Schorfheide, 2009; Leist and Neusser, 2010). Bäurle and Menz (2008), Beltran and Draper (2008) and Rudolf and Zurlinden (2011) estimate a DSGE model for the Swiss economy, but they do not focus on the analysis of the output gap. The approach here is related to the unconditional output gap discussed in Adolfson et al (2011). As in Beltran and Draper (2008) and Adolfson et al (2011), the estimate of the natural output gap is a function of model variables. The contribution of this paper is the exploitation of the model-based formulation of the output gap to identify its driving forces in order to analyze recessions using a small open economy model. This approach allows for a more thorough understanding of recessions compared to pure statistical procedures or unobserved components methods.

This paper follows the recent literature, uses a New Keynesian small open economy DSGE model to estimate the Swiss output gap, and relies on the model of Monacelli (2005) and the adaption by Beltran and Draper (2008). Deviations from the classical small open economy model by Galí and Monacelli (2005) include the introduction of a law of one price (LOP) gap and the inclusion of habit persistence and indexation. The inclusion of a LOP gap is motivated by Campa and Goldberg (2005) and Bachmann (2012) who find a deviation from the LOP in the short run. The foreign economy is approximated by a VAR(2). Different model specifications are estimated using Bayesian estimation techniques as exposed in AN and SCHORFHeIDE (2007).

The model comparison based on marginal densities leads to the conclusion that the output gap matters for Switzerland. Furthermore, a comparison of the model-based output gap to conventional measures of economic fluctuations such as HP-cycle, detrended output and GDP growth yields the conclusion that the model-based output gap evolves much like these measures. However, contrary to conventional approaches, the model-based approach enables one to perform a shock decomposition. The Swiss output gap is mainly driven by foreign 
output shocks, foreign interest rate shocks and shocks to the uncovered interest rate parity (UIP). Comparing the three main recessions contained in the sample reveals surprising changes in the evolution of the shock contributions. While the first recession (1994:3 to 1999:2) and the second recession (2001:4 to 2006:1) were characterized by a procyclical effect of the UIP shock, this relationship breaks down during the last recession (2008:4 to 2010:2). The average of the UIP shock in the first two recessions is negative, reflecting a lower risk premium demanded by economic agents. However, the average UIP shock was positive during the last recession. The demanded risk premium is reflected in higher interest rates and a depreciated domestic currency that induces a positive output gap. In contrast to previous recessions, the UIP shock played a minor role during the last recession where the foreign output shock dominated.

Section 2 discusses the model with a focus on the output gap in an otherwise standard small open economy model with incomplete pass through. Section 3 presents the estimation strategy including a thorough discussion of the data and prior distribution. Different model specifications are compared at the beginning of section 4 and the Bayes factor is used to choose the model that best fits the data. In section 5, impulse response functions and the shock decomposition are given for the model that best fits the data. Section 6 concludes the paper.

\section{The Model}

This section introduces the small open economy New Keynesian DSGE model used in the following analysis. The specification of the model closely follows Beltran and Draper (2008), who extended the Monacelli (2005) model by introducing habit persistence. The main elements of the model are as follows. The domestic economy is populated by households, producers and retailers. Utility maximizing, infinitely lived households choose between consumption and labor, where consumption is given relative to a time varying external habit persistence. The consumption good is given by a bundle of domestically produced and imported goods. Monopolistic competitive firms decide on labor input and produce differentiated domestic goods. Domestic producers and retailers are subject to Calvo-style price setting. In contrast to Beltran and Draper (2008), the model incorporates indexation such that firms or retailers not able to reoptimize partially index their price to past inflation. Unlike the standard small open economy model by Galí and MonaCelli (2005), it is not assumed that the LOP holds. Retail firms import differentiated goods and the LOP holds at dock. However, due to the optimization by retailers to set the domestic currency price 
in the presence of staggered price setting, short run deviations from the LOP are introduced. CAMPA and GoldBerg (2005) show that the degree of import passthrough elasticities is low in the short run and close to one in the long run for a range of OECD countries including Switzerland. This finding is confirmed by BaChmann (2012), who uses a vector error correction model to analyze Swiss data in contrast to the single equation approach pursued by CAMPA and GoLDBERG (2005). The log-linearized equations that describe this model and are used for estimation are provided herein. ${ }^{1}$ The small letter variables denote percentage deviations of the variables from their respective steady state. ${ }^{2}$

The small open economy is considered to be negligible compared to the rest of the world. Therefore, we can treat the foreign economy as a closed economy. For our purposes, we will approximate the foreign economy by a VAR process using data on foreign output $\left(y_{t}^{*}\right)$, foreign inflation $\left(\pi_{t}^{*}\right)$ and foreign interest rates $\left(i_{t}^{*}\right)$.

The New Keynesian Phillips Curve (NKPC) for domestic goods prices $\left(P_{H, t}\right)$ is derived from the optimization of domestic producers. They produce the domestic good and sell it in domestic and foreign markets. It is assumed that they face monopolistic competition and Calvo-style price setting where $\theta_{H}$ is the probability for a firm not to be able to adjust prices. If a firm is not able to reoptimize, prices are partially indexed to lagged inflation. Calvo pricing and indexation introduces sluggish adjustment of prices to their desired level. Domestic inflation $\left(\pi_{H, t}=p_{H, t}-p_{H, t-1}\right)$ is given by

$$
\begin{gathered}
\pi_{H, t}=\delta_{H} \pi_{H, t-1}+\beta \mathbb{E}_{t}\left(\pi_{H, t+1}-\delta_{H} \pi_{H, t}\right)+\kappa_{H} m c_{t}+\varepsilon_{\pi_{H}, t} \\
\text { where } \kappa_{H} \equiv \frac{\left(1-\theta_{H}\right)\left(1-\beta \theta_{H}\right)}{\theta_{H}}
\end{gathered}
$$

with $0<\beta<1$ being the discount factor, $\delta_{H}$ the indexation parameter and $\varepsilon_{\pi_{H_{H}, t}}$ denoting an exogenous shock. In contrast to the standard SOE model by Galí and Monacelli (2005), there are also retailers in the domestic economy. They import differentiated goods at world market prices and the LOP holds at the docks. However, they are also facing monopolistic competition as well as

1 Readers interested in a detailed exposition of the model are referred to the appendix of the working paper version of this paper (LEIST, 2011). In contrast to the working paper, the model is estimated assuming log utility in consumption. However, the main results are independent of this specification.

2 In contrast to Leist (2011), the hat notation $\hat{a}_{t}$ to denote percentage deviations of a variable $A_{t}$ from its steady state is neglected to enhance readability. 
staggered price setting and indexation. This leads to short-run deviations from the LOP while it still holds in the long run. From the optimization of the retailers, the NKPC for imported inflation $\left(\pi_{F, t}=p_{F, t}-p_{F, t-1}\right)$ can be derived, where $P_{F, t}$ is the price index of import goods such that

$$
\begin{gathered}
\pi_{F, t}=\delta_{F} \pi_{F, t-1}+\beta \mathbb{E}_{t}\left(\pi_{F, t+1}-\delta_{F} \pi_{F, t}\right)+\kappa_{F} \psi_{F, t}+\varepsilon_{\pi_{F}, t} \\
\text { where } \kappa_{F} \equiv \frac{\left(1-\theta_{F}\right)\left(1-\beta \theta_{F}\right)}{\theta_{F}} .
\end{gathered}
$$

$\varepsilon_{\pi_{F}, t}$ denotes an exogenous shock and $\psi_{F, t}=s_{t}+p_{t}^{*}-p_{F, t}$ denotes the deviation from the LOP from its steady state. The probability that a retailer is not able to adjust its prices is given by $\theta_{F}$, and $\delta_{F}$ is the indexation parameter of retailers.

Defining the $\log$ of terms of trade as $x_{t} \equiv \log \left(P_{F, t} / P_{H, t}\right)$, the log-linearized consumer price index $\left(\pi_{t}\right)$ is given by

$$
\pi_{t}=\pi_{H, t}+\gamma \Delta x_{t}=(1-\gamma) \pi_{H, t}+\gamma \pi_{F, t}
$$

where $\gamma$ denotes the share of foreign goods in the consumption bundle. The change in terms of trade can be denoted by

$$
\Delta x_{t}=\pi_{F, t}-\pi_{H, t}
$$

The real exchange rate is given by

$$
q_{t}=s_{t}+p_{t}^{*}-p_{t}=(1-\gamma) x_{t}+\psi_{F, t}
$$

where $s_{t}$ is the nominal exchange rate. The change of the LOP gap is given by

$$
\Delta \psi_{F, t}=\Delta s_{t}+\pi_{t}^{*}-\pi_{F, t}
$$

where $\pi_{t}^{*}$ represents the inflation of the foreign consumer price index.

The following equation is derived using the assumption of internationally complete asset markets. This assumption implies that the domestic household Euler equation can be equated to the foreign Euler equation (in the spirit of CHARI, Kehoe, and McGrattan (2002) and Galí (2008)). Therefore, home consumption $\left(c_{t}\right)$ depends on foreign output $\left(y_{t}^{*}\right)$ as well as on the terms of trade and on the LOP gap 


$$
\left(c_{t}-h c_{t-1}\right)=\left(y_{t}^{*}-h y_{t-1}^{*}\right)+(1-h)\left[(1-\gamma) x_{t}+\psi_{F, t}\right]
$$

where $h$ is the degree of habit persistence. From the completeness of asset markets assumption, we also obtain the uncovered interest parity condition, which, after some manipulations, can be written as

$$
\left(i_{t}-E_{t} \pi_{t+1}\right)=\left(i_{t}^{*}-\mathbb{E}_{t} \pi_{t+1}^{*}\right)+\mathbb{E}_{t}\left[\Delta q_{t+1}\right]+\varepsilon_{q, t}
$$

where $i_{t}$ is the domestic interest rate, $i_{t}^{*}$ is the foreign interest rate, $\pi_{t}^{*}$ is foreign inflation and $\varepsilon_{q, t}$ denotes an exogenous shock.

Real marginal costs $m c_{t}=w_{t}-p_{H, t}-z_{t}$, where $w_{t}$ are wages and $z_{t}$ is productivity, are derived from the cost minimization of firms. Then, the log linearized household first-order condition with respect to labor input $\left(N_{t}\right)$ as well as the definition of the terms of trade are used to derive

$$
m c_{t}-\gamma x_{t}=\varphi y_{t}-(1+\varphi) z_{t}+(1-h)^{-1}\left(c_{t}-h c_{t-1}\right)
$$

where $y_{t}$ denotes domestic output and $\varphi$ denotes the inverse of the labor supply elasticity. As Monacelli (2005) notes, the real marginal costs are affected by foreign output $y_{t}^{*}$ via risk sharing through its effect on labor supply as well as by a "relative price effect" captured by the terms of trade and the LOP gap (see equation (7)).

The market clearing equation is derived from imposing the rule that the domestic output must equal the consumption of domestic goods plus the net exports of domestic goods. Plugging in the demand functions for these goods yields the market clearing condition

$$
(1-\gamma) c_{t}=y_{t}-\gamma \eta(2-\gamma) x_{t}-\gamma \eta \psi_{F, t}-\gamma y_{t}^{*}
$$

where $\eta$ is the substitution elasticity between domestic and foreign goods.

Regarding the monetary policy (MP), several standard MP rules are assumed. They are all of the form

$$
i_{t}=\rho_{i} i_{t-1}+\left(1-\rho_{i}\right)\left(\psi_{\pi} \pi_{t}+\psi_{a} a_{t}+\psi_{s} \Delta s_{t}\right)+\varepsilon_{i, t}
$$

where $a_{t}$ is either detrended output $\left(y_{t}\right)$, output growth $\left(\Delta y_{t}+z_{t}\right)$ or the natural output gap $\left(\tilde{y}_{t}=y_{t}-y_{t}^{\text {flex }}\right.$ where $y_{t}^{\text {flex }}$ is natural output). $\varepsilon_{i, t}$ denotes an exogenous interest rate shock. 
To derive the natural output gap ${ }^{3}$, we use the fact that deviation of marginal costs from steady state (the desired markup) is zero under flexible prices. Furthermore, the LOP holds under flexible prices. Defining the output gap as the difference between output and output under flexible prices a model-based measure of the output gap can be derived. However, the DSGE model for the foreign closed economy is approximated by a VAR. Hence, there will be a slight modification compared to the complete structural model when implementing the DSGE model for estimation. The approximation by a VAR implies that the foreign technology $z_{t}^{*}$ and the foreign flexible price output $y_{t}^{* f e x}$ are not implemented into the equilibrium conditions. Hence, $y_{t}^{*}$ is used as a proxy for $y_{t}^{* f l e x}$ and $z_{t}^{*}$ in the equation of the domestic flexible price output and in the equation of domestic terms of trade under flexible prices. Therefore, the domestic output gap is given by ${ }^{4}$

$$
\tilde{y}_{t}=y_{t}-y_{t}^{f l e x}
$$

$$
\text { where } \begin{aligned}
y_{t}^{f l e x} & =\frac{1+\varphi}{\varphi} z_{t}-\frac{x_{t}^{f l e x}}{\varphi}+\phi_{y y^{*}} y_{t}^{*} \\
x_{t}^{f l e x} & =A x_{t-1}^{f f e x}+B\left[z_{t}-h z_{t-1}\right]-\phi_{x z^{*}} y_{t}^{*} \\
A & =\frac{h[\varphi \gamma \eta(2-\gamma)+1]}{[\varphi \gamma \eta(2-\gamma)+1]+(1-h)(1-\gamma)^{2} \varphi} \\
B & =\frac{(1+\varphi)}{[\varphi \gamma \eta(2-\gamma)+1]+(1-h)(1-\gamma)^{2} \varphi}
\end{aligned}
$$

3 The literature makes a distinction between the potential (or efficient) output and natural (or flexible price) output. The former is the level of output under flexible prices and perfect competition. The latter is the level of output under imperfect competition, but with flexible prices. The term output gap in this paper always refers to the difference between the output and the natural (flexible price) level of output. McCallum and Nelson (1999), McCallum (2001) and Neiss and Nelson (2005) identify the natural level of output as most appropriate theoretically to inform central banks about disequilibria caused by nominal rigidities.

4 The coefficients $\phi_{y y^{*}}$ and $\phi_{x z^{*}}$ are not identified. Restricting the latter to be zero would not change the results presented in the remainder of this paper 
For the productivity shock, we assume an $\mathrm{AR}(1)$ process:

$$
z_{t}=\rho_{z} z_{t-1}+\varepsilon_{z, t}
$$

All domestic shocks $\left(\varepsilon_{\pi_{H}}, \varepsilon_{\pi_{F}}, \varepsilon_{q}, \varepsilon_{i}, \varepsilon_{z}\right)$ follow an $\mathrm{AR}(1)$ process.

The foreign economy is approximated by a VAR. ${ }^{5}$

$$
\begin{aligned}
\left(\begin{array}{l}
y_{t}^{*} \\
\pi_{t}^{*} \\
i_{t}^{*}
\end{array}\right)=\mathbf{A}_{1}\left(\begin{array}{l}
y_{t-1}^{*} \\
\pi_{t-1}^{*} \\
i_{t-1}^{*}
\end{array}\right)+\mathbf{A}_{2}\left(\begin{array}{l}
y_{t-2}^{*} \\
\pi_{t-2}^{*} \\
i_{t-2}^{*}
\end{array}\right)+\mathbf{B}_{1} \varepsilon_{\mathbf{t}} \\
\text { with } \mathbf{A}_{1}=\left(\begin{array}{lll}
a_{11} & a_{12} & a_{13} \\
a_{21} & a_{22} & a_{23} \\
a_{31} & a_{32} & a_{33}
\end{array}\right), \mathbf{A}_{2}=\left(\begin{array}{lll}
a_{14} & a_{15} & a_{16} \\
a_{24} & a_{25} & a_{26} \\
a_{34} & a_{35} & a_{36}
\end{array}\right), \\
\mathbf{B}_{1}=\left(\begin{array}{lll}
b_{11} & 0 & 0 \\
b_{21} & b_{22} & 0 \\
b_{31} & b_{32} & b_{33}
\end{array}\right) .
\end{aligned}
$$

The vector $\varepsilon_{t}$ contains the exogenous i.i.d. shocks to foreign output, foreign inflation and foreign interest rate and is given by $\left[\varepsilon_{y^{*}, t}, \varepsilon_{\pi^{*}, t}, \varepsilon_{i^{*}, t}\right]$.

\section{Estimation}

The Bayesian estimation strategy as exposed in An and SCHORfHeide (2007) and Fernández-Villaverde (2009) is applied. ${ }^{6}$ A full-information likelihood approach is chosen to use all information implied by the model. The Kalman filter provides the possibility to evaluate the implied likelihood function $\mathcal{L}(\mathrm{Y} \mid \Theta)$ derived from the DSGE model.

The likelihood will be augmented by a prior distribution $\pi(\Theta)$ to obtain the posterior distribution of parameters $\mathcal{P}(\mathrm{Y} \mid \Theta)$. Recall that the joint probability of $(\mathrm{Y}, \Theta)$ is given by

5 The information criteria AIC, BIC and HQ all favor a VAR with two lags.

6 To estimate the model, own code based on BÄUrle and Menz (2008) as well as Dynare (Adjemian et al., 2012) was used. 


$$
p(\mathrm{Y}, \boldsymbol{\Theta})=\mathcal{L}(\mathrm{Y} \mid \Theta) \pi(\boldsymbol{\Theta})
$$

or

$$
p(\mathrm{Y}, \boldsymbol{\Theta})=\mathcal{P}(\boldsymbol{\Theta} \mid \mathrm{Y}) p(\mathbf{Y})
$$

and by inserting the former into the latter, we obtain the posterior distribution

$$
\mathcal{P}(\Theta \mid \mathrm{Y})=\frac{\mathcal{L}(\mathrm{Y} \mid \boldsymbol{\Theta}) \pi(\boldsymbol{\Theta})}{p(\mathrm{Y})} \propto \mathcal{L}(\mathrm{Y} \mid \Theta) \pi(\Theta)
$$

There is no analytical solution available due to the non-linear mapping from the DSGE model parameters to the moments of the data. Therefore, numerical methods are used. The first estimation approach relies on Sims' algorithm csminwel ${ }^{7}$ to minimize over the objective given by

$$
f(\Theta)=-\ln \mathcal{L}(\mathbf{Y} \mid \Theta)-\ln \pi(\Theta)
$$

Numerical methods are applied to calculate the posterior moments of DSGE model parameters. To this end, the Random-Walk Metropolis-Hastings algorithm and estimation setup as exposed in LubiK and SchorfHeide (2006), AN and Schorfheide (2007) and Fernández-Villaverde (2009) is used. Furthermore, modified harmonic mean estimates of the marginal densities are computed to compare the models (see Geweke (1999), Rabanal and Rubio-Ramirez (2005) and An and SchorfHeide (2007)).

\subsection{Data}

The model is estimated using quarterly data ranging from 1989:1 to 2010:2. ${ }^{8}$ Higher frequency data are transformed to quarterly data by taking averages. Data on the Swiss GDP growth rates, import price inflation, CPI inflation, 3-month LIBOR in CHF, the real exchange rate, GDP growth rates and inflation of OECD countries and the interest rate on the EURO are used.' Quarterly data

7 The program code can be found on http://www.princeton.edu/ -sims/.

8 The data sources do not provide information on the 3-month LIBOR in CHF prior to 1989.

9 Data on interest rates are not available for all OECD countries for the sample of interest. Hence, the EUR interest rate is used. Note that approximately $78 \%$ of imports and approximately 56\% of exports are due to trades with EUR countries (Data for 2010 taken from 
on the seasonally adjusted real GDP of Switzerland is taken from the Swiss State Secretariat for Economic Affairs (SECO) and transformed to quarterly growth rates by taking log differences and multiplying by 100. Swiss inflation rates are defined as percentage changes of CPI to the corresponding month of the previous year. The data is taken from the monthly bulletin of the Swiss National Bank (SNB). The monthly import price index is obtained from the SNB and transformed to annualized percentage rates by multiplying the log-differences by 400 . The interest rate is defined as the 3 -month-LIBOR. The monthly series is obtained from Econstats ${ }^{10}$ for observations up to 1998. For later observations, data provided by the SNB are used. Quarterly data on the relative consumer price index supplied by the OECD provide information on the real exchange rate. The series is detrended by regressing it on a constant as well as on a trend and by then multiplying the respective residuals by 100 . As a measure of foreign output, the seasonally adjusted quarterly real GDP of OECD countries is taken. The series is detrended in the same manner as the real exchange rate. Detrended data are used instead of growth rates due to the approximation of the foreign economy by a $\operatorname{VAR}(2) .{ }^{11}$ The quarterly series on percentage changes of the consumer price index of OECD countries on the same period of the previous year is the measure for foreign inflation. The foreign interest rate is defined as the quarterly EURO short-term interest rate. The data source used is the Area Wide Model (AWM) dataset for the years up to 2008 and the short-term interest rate of the EURO provided by the OECD for the remaining observations. ${ }^{12}$ The mean is subtracted from all series prior to estimation. A detailed overview of the data is given in Table 1.

http://www.ezv.admin.ch/themen/00504/01506/01533/index.html?lang=de). Therefore, the EUR interest rate occurs to be an accurate measure to use for the foreign interest rate. Furthermore, as a robustness check, data on the GDP for the EURO area and CPI for the EURO area were used. The results are similar to the ones reported in this paper.

10 http://www.econstats.com/r/rlib_em $4 . h t m$

11 Foreign GDP growth corresponds to $\Delta y_{t}^{*}+z_{t}^{*}$ in the model. However, foreign productivity is not modeled due to the approximation by a $\operatorname{VAR}(2)$.

12 See Fagan, Henry, and Mestre (2001) or http://www.eabcn.org/area-wide-model for a description of the AWM dataset. 


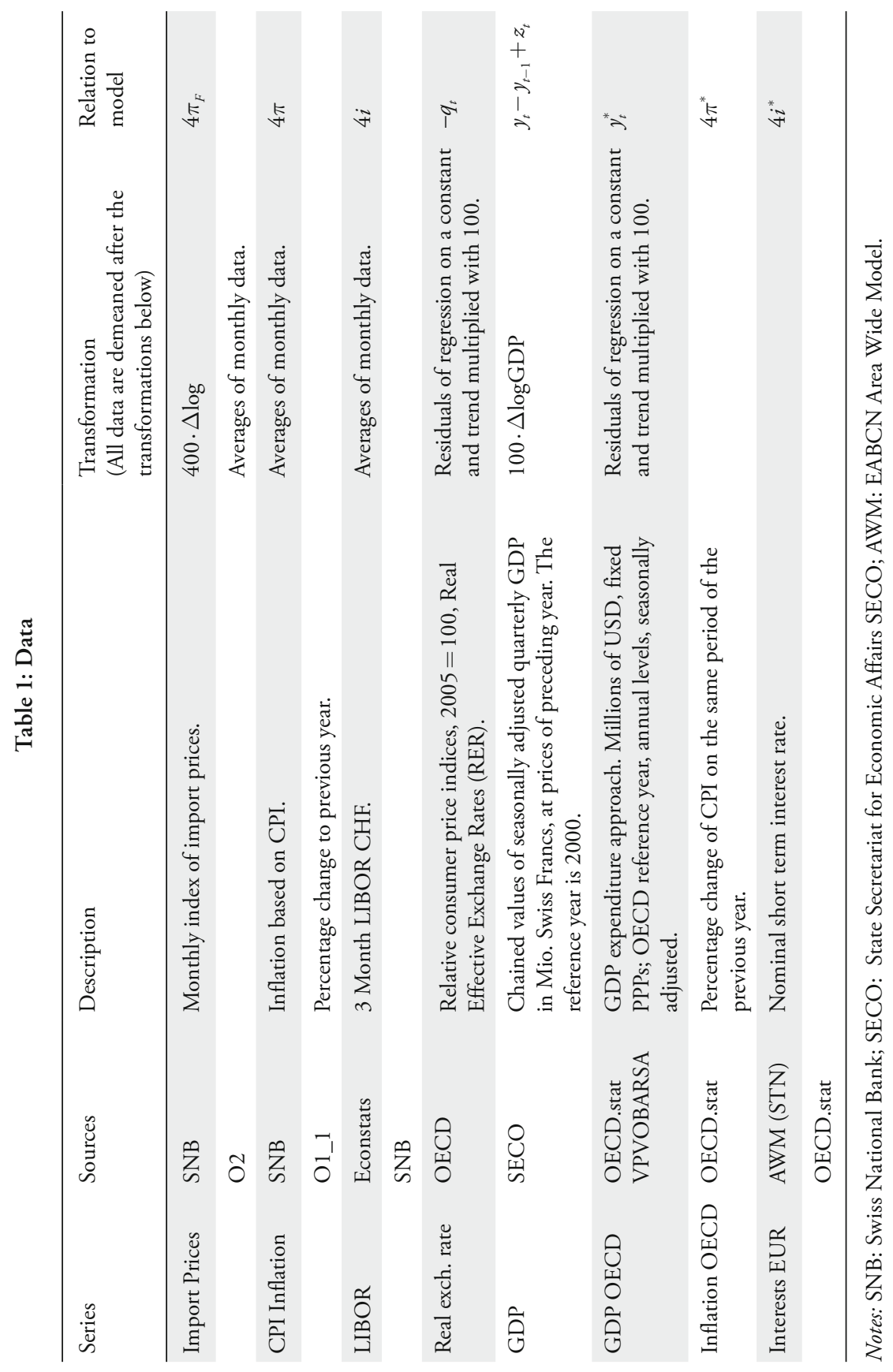




\subsection{Prior Specification}

The prior distribution is determined by relying on a priori beliefs from past studies and is reported in Table 3. In the first column, the parameter symbol is given. The second column reports the chosen prior mean. The third column exhibits the prior standard deviation, while the fourth column specifies the assumed distribution for any given parameter. As the prior distribution is an important part of the Bayesian estimation, some space will be devoted to discuss its specifications.

\subsubsection{Calibrated Parameters}

The parameters that are not estimated are discussed prior to the discussion of the estimated parameters. As is commonly found in the literature, the discount factor, $\beta$, is set to 0.9961 , implying an annual steady-state real interest rate of $1.6 \%$. The share of imported goods in the small open economy's consumption bundle, $\gamma$, is fixed at 0.25 for identification reasons, as the average ratio of imported goods to the Swiss GDP lies in this region. Finally, we estimate a VAR(2) process for the foreign economy.

\subsubsection{Prior Distributions}

The degree of habit persistence must lie between zero and one. Therefore, a beta distribution is assumed. There are a few studies (e.g., FuHrer (2000) and CHRIstiano, Eichenbaum, and Evans (2005)) that find estimates for $h$ of approximately 0.6 and 0.8 . However, while a mean of 0.5 is used, it is allowed to vary.

The mean of the inverse labor supply elasticity and the mean of the substitution elasticity between domestic and foreign goods are set to one as is commonly found in the literature (Christiano, Eichenbaum, and Evans, 2005; Corsetti and Pesenti, 2005). Both parameters are assumed to follow a gamma distribution.

The fraction of firms not able to adjust their prices is set to 0.75 , which implies an average duration between price changes of 4 months. ${ }^{13}$ As the price stickiness parameters reflect probabilities, they must lie between zero and one. This is reflected by the assumption that they follow a beta distribution.

Productivity shocks are assumed to be highly persistent. Therefore, the prior mean for the autoregressive coefficient in the exogenous technology process is set to 0.9 . Furthermore, most empirical studies of monetary policy rules have found

13 See Kaufmann (2009) for microeconomic evidence on Switzerland. 
a large degree of interest rate smoothing. ${ }^{14}$ Hence, we set the prior mean to 0.7 . For these autoregressive coefficients, only values between zero and one are reasonable, and therefore, a beta distribution is assumed.

Finally, for the case of Switzerland, it seems reasonable to assume a rather strong reaction of the monetary authority to inflation and, in comparison, a rather modest reaction to real economic activity. Therefore, the value 1.5 as a reaction to inflation and 0.5 as a reaction to a measure of real economic activity is chosen. The parameters are assumed to follow a gamma distribution as only positive values appear reasonable. Furthermore, the prior mean for the reaction of the monetary authority to changes in the nominal exchange rate is assumed to be 0.25 and follows a normal distribution. Note that this parameter is not present in each Taylor rule of the different models. The prior mean of the indexation parameters is set to 0.5 and assumed to follow a normal distribution with a standard deviation of 0.20 .

The term $\phi_{y y}^{*} \cdot y^{*}$ approximates the effect of foreign productivity and the foreign natural output on domestic natural output. The prior mean is set to one, but the parameter is allowed to vary substantially. As there is no a priori information on the reaction of flexible terms of trade to foreign output available, a zero mean and a high variance are assumed for $\phi_{x z^{*}}^{*}$. For both parameters, a normal distribution is assumed.

The AR(1) coefficients in the shock processes are denoted by $\rho_{\varepsilon_{j}}$, where $j$ is the corresponding shock. The prior mean for all these coefficients is set to 0.5 , and 0.2 is the prior standard deviation. All standard deviations of domestic shocks are assumed to have a mean of 0.1 and follow an inverse gamma distribution.

\section{Estimation Results}

As given in equation (11), different Taylor rules are estimated because this equation is based on ad-hoc assumptions. Hence, it is advisable to explore which specification performs best at fitting the data. Five different models containing reasonable Taylor rules are considered. In the first model, (BASE), the monetary authority is assumed to react to inflation and the natural output gap. The second model, (GROW), stipulates a Taylor rule where the monetary authority reacts to inflation and output growth. The third model, (DETR), assumes that the monetary authority reacts to inflation and detrended output. The fourth

14 See for example Clarida, Gali, and Gertler (1998), Lubik and Schorfheide (2007), and Justiniano and Preston (2010b). 
model, $(\mathrm{EXCH})$, considers a reaction of the monetary authority to inflation, to the natural output gap and to the exchange rate. Finally, the model IND has the same specification as model $\mathrm{EXCH}$, but additionally it allows for indexation in the New Keynesian Phillips Curves. An overview of the Taylor rule specifications is provided in Table 2.

Table 2: Model Overview

The table shows which variables are present in the Taylor Rule of the respective model and whether indexation in NKPCs is considered.

\begin{tabular}{lccccc}
\hline Variables / Model & BASE & GROW & DETR & EXCH & IND \\
\hline Inflation & + & + & + & + & + \\
Output Gap & + & & & + & + \\
GDP Growth & & + & & & \\
Detrended GDP & & & + & & + \\
Exchange Rate & & & & + & + \\
Indexation & & & & & + \\
\hline
\end{tabular}

\subsection{Estimated Parameters}

The estimation results are presented in Table 3. The second column reports the specified prior mean as discussed in section 3.2. The third column reports the prior standard distribution. The following columns report the posterior means and posterior standard deviations for the estimated models.

Similar to Beltran and Draper (2008), the degree of habit persistence (b) is high for all considered model specifications. These estimates are a bit higher than those usually found in the literature. ${ }^{15}$ The parameter of the inverse elasticity of labor supply $(\varphi)$ is slightly lower compared to other studies for most of the chosen model specifications. ${ }^{16}$ This implies that the labor supply is quite responsive to changes in real wages. The elasticity of substitution between domestic and foreign goods $(\eta)$ is very low ${ }^{17}$, while the degree of price stickiness for domestic

15 See, e.g., Fuhrer (2000), Christiano, Eichenbaum, and Evans (2005) and Adolfson et al. (2007).

16 See, e.g., Beltran and Draper (2008), Justiniano and Preston (2010b) and Justiniano and Preston (2010a).

17 This is consistent with the findings of Hooper, Johnson, and Marquez (1998). They report an elasticity of 0.6 for the U.S. while the remaining G7 countries exhibit elasticities between 
producers $\left(\theta_{H}\right)$ and for domestic retailers $\left(\theta_{F}\right)$ is rather high. This implies that firms seldom reoptimize which is in contrast to the microeconomic evidence (Kaufmann, 2009). However, Justiniano and Preston (2010a) find similar results for domestic price stickiness, though not for the imported price stickiness when using a small open economy model for Canada. Furthermore, as the model IND allows for indexation, price changes are more often observed. The monetary authority strongly reacts to inflation but not so much to the real economic activity with the exception of the reaction to growth rate (GROW model). It also reacts to changes in the exchange rate when it is allowed to. The indexation parameters are higher than otherwise found in the literature (e.g. e.g. BëURLE and Menz (2008) or Justiniano and Preston (2010b)). Finally, technology and the interest rate are highly persistent processes.

\subsection{Model Comparison}

The log marginal likelihoods are compared following the approach of AN and SCHORfHEIDE (2007) to evaluate the performance of the different models at explaining the data. The log marginal likelihood and the Bayes factor (BF) are reported in the last rows of Table 3 . The BF is given by

$$
B F_{I N D, j}=\exp \left\{\ln p\left(\mathrm{Y} \mid M_{\mathrm{IND}}\right)-\ln p\left(\mathrm{Y} \mid M_{j}\right)\right\}
$$

where $\ln p\left(\mathrm{Y} \mid M_{j}\right)$ is the log marginal likelihood of model $i$. As in LubiK and Schorfheide (2007) and Justiniano and Preston (2010b), it can be concluded that including a reaction to changes in the nominal exchange rate in the Taylor rule is favored by the data. Most importantly, the models that are superior with respect to the log marginal likelihood all include the natural output gap in the Taylor rule. Therefore, estimating the output gap instead of just using the growth rate or detrended GDP improves the explanatory power of the model. The table reports the BF for the comparison of model IND to the other models. KASS and RAFTERY (1995) suggest that values of $2 \ln (B F)>10$ indicate very strong evidence against model $j$. Hence, allowing for indexation improves the models ability to predict data as all $\mathrm{BF}$ are greater than $10 .{ }^{18}$ While the discussion in

0 and 0.6. Furthermore, the estimate is close to the findings of TAYLOR (1993). He reports elasticities between 0 and 0.19 for European countries.

18 The DSGE model was also estimated using the HP-cycle of the Swiss GDP as observable instead of the growth rate. The log marginal likelihood using this approach was also lower than for the models with the output gap. However, as observables were exchanged to include the HP-cycle in the Taylor rule, this result must be taken with caution. 


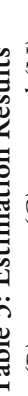

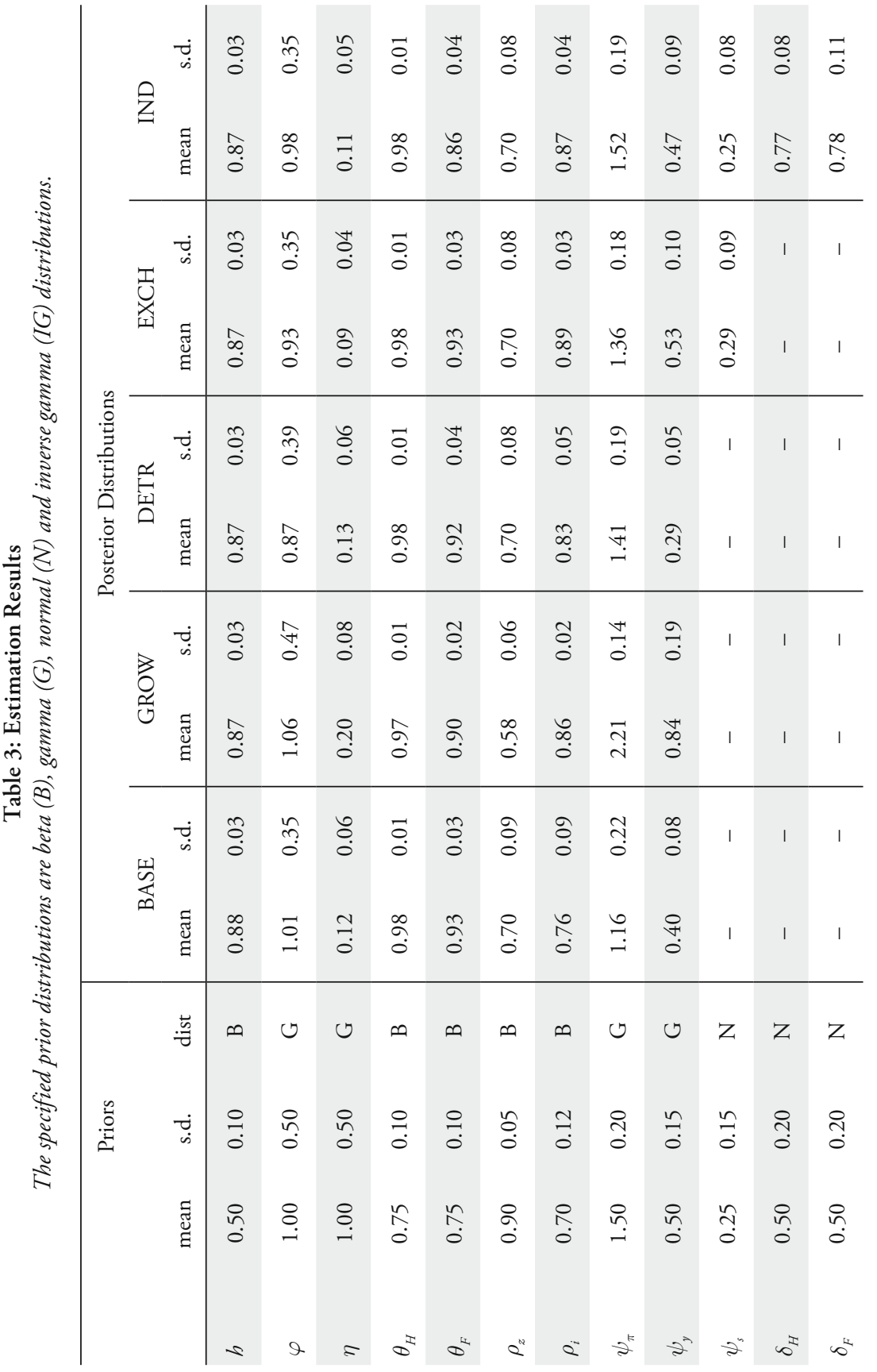




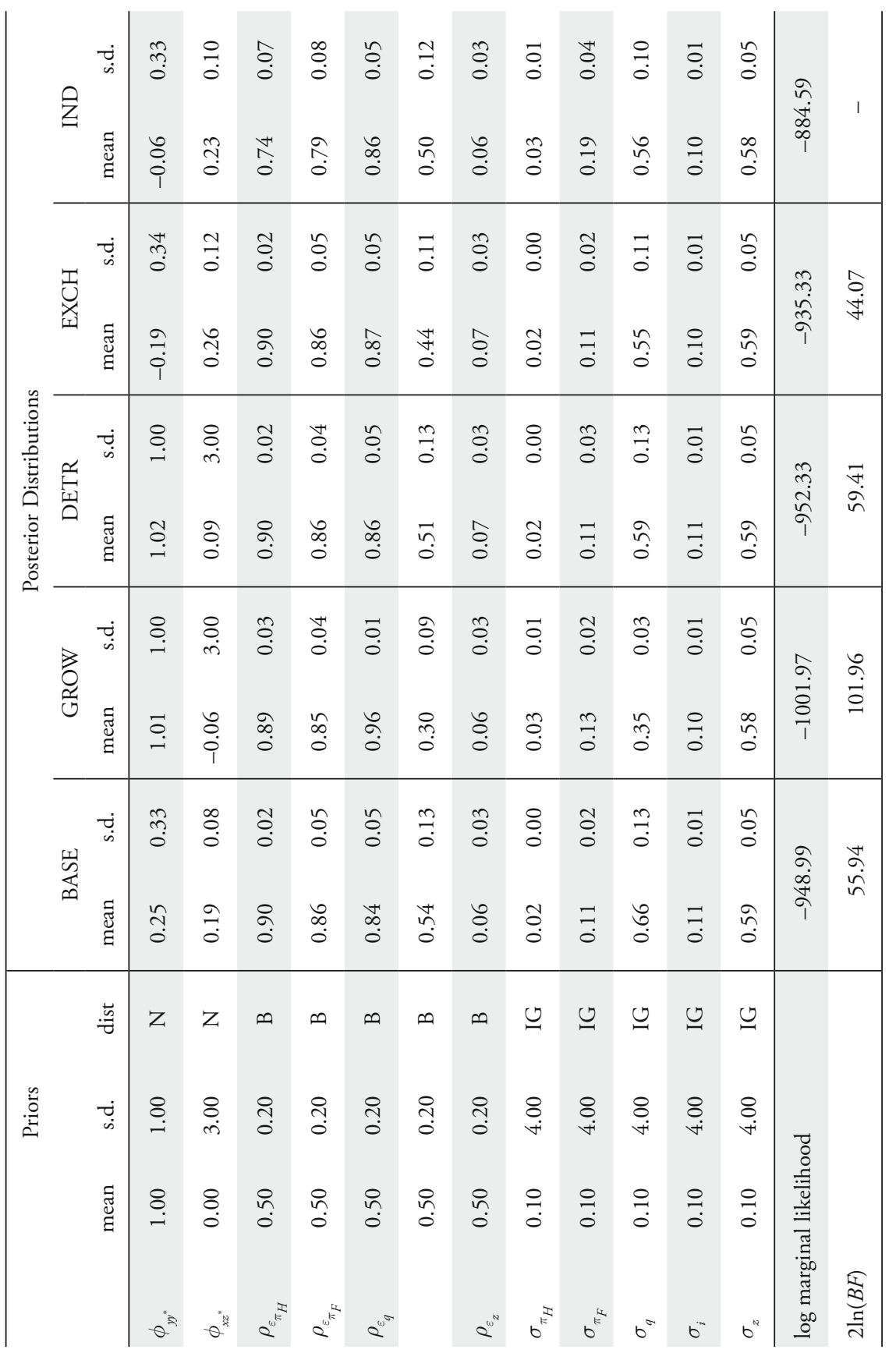


the remainder of the paper relies on results from the model with indexation and with the exchange rate in the Taylor rule (model IND), the results regarding the impulse response functions as well as the shock decomposition of output are robust across the different model specifications.

\subsection{Impulse Responses}

Insights on the behavior of endogenous variables can be gained by examining the impulse response functions of selected variables. The impulse response functions display the median response to a shock of the size of one standard deviation together with a 90\% credible interval. Figure 1 displays the responses to a positive domestic productivity shock. It raises output significantly but less pronounced than natural output. The reason is that the deviation of marginal costs from constant steady state markup $\left(\widehat{m c}_{t}\right)$ reacts negatively to a productivity shock. As prices cannot adjust immediately, the effect of a positive productivity shock on output is dampened compared to its effect on natural output. Therefore, the output gap reacts negatively to a productivity shock, and the reaction of prices is economically irrelevant due to the small size. The interest rate decreases in response to a productivity shock. As the foreign inflation is exogenous and the Swiss CPI inflation hardly reacts, the domestic currency depreciates. Hence, the real exchange rate depreciates.

A positive interest rate shock of the size of one standard deviation leads to an appreciation of the real exchange rate because the nominal exchange rate appreciates more than the domestic price level (Figure 2). The inflation rate decreases as well, although the effect dies out rather quickly. The hump shaped response is only achieved by allowing for indexation. Output falls after an interest rate shock. Furthermore, the natural level of output does not react to an interest rate shock. Therefore, the reaction of the output gap in response to an unexpected interest rate shock corresponds to the reaction of output.

Figure 3 displays the responses to a shock to foreign output. Foreign demand for home goods increases, thus leading to an increased output gap. The nominal exchange rate depreciates, and in combination with the increase of the foreign price level, this explains the depreciation of the real exchange rate. The increased demand leads to an increase in CPI inflation that is counteracted with a lagged increase of domestic interest rates.

The responses to a one standard deviation shock to the uncovered interest rate parity (UIP) are depicted in Figure 4. This shock can be interpreted as a risk premium shock. It has an important effect on the real exchange rate through the nominal exchange rate. The increase in the real exchange rate coincides with 

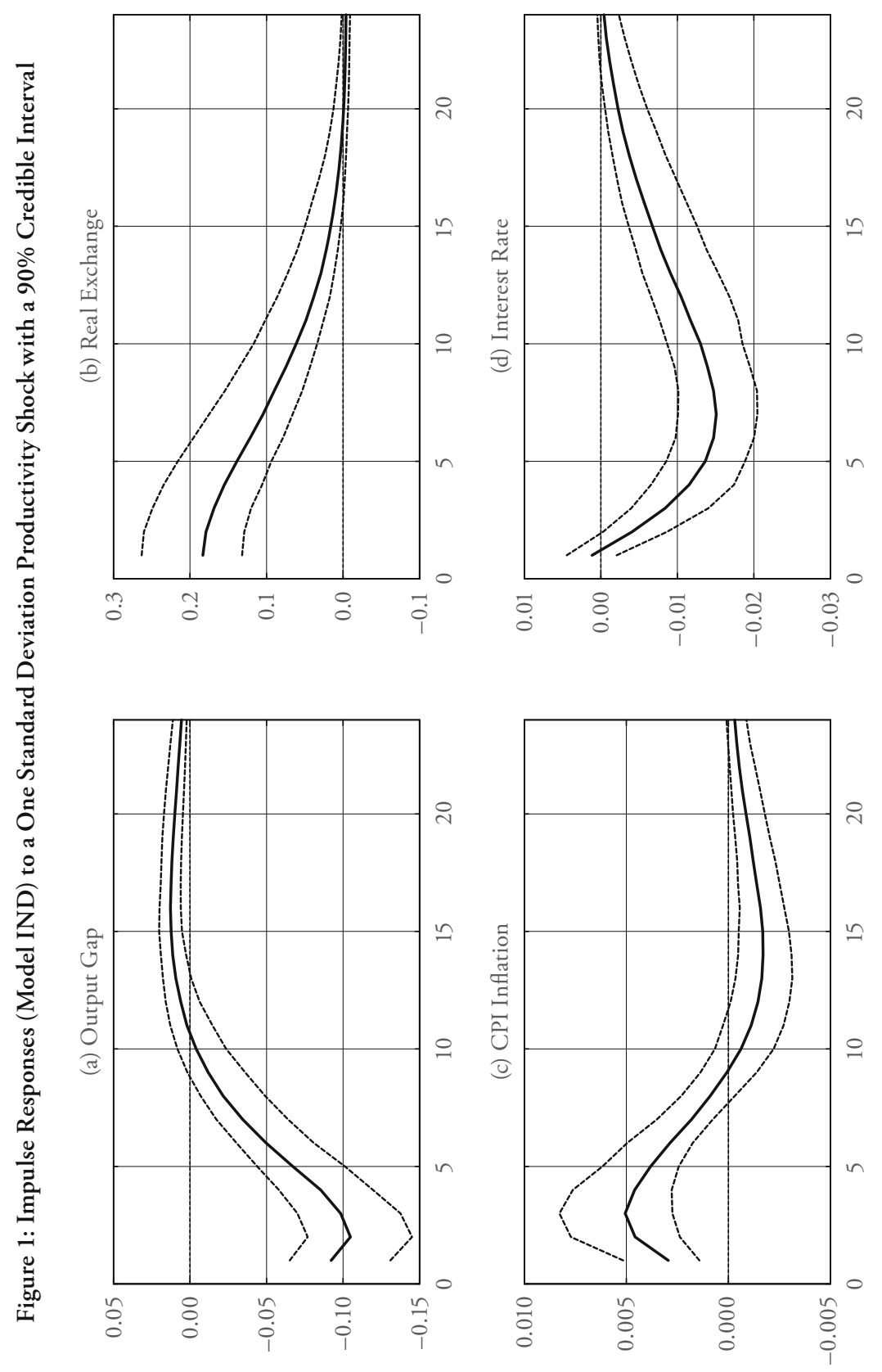

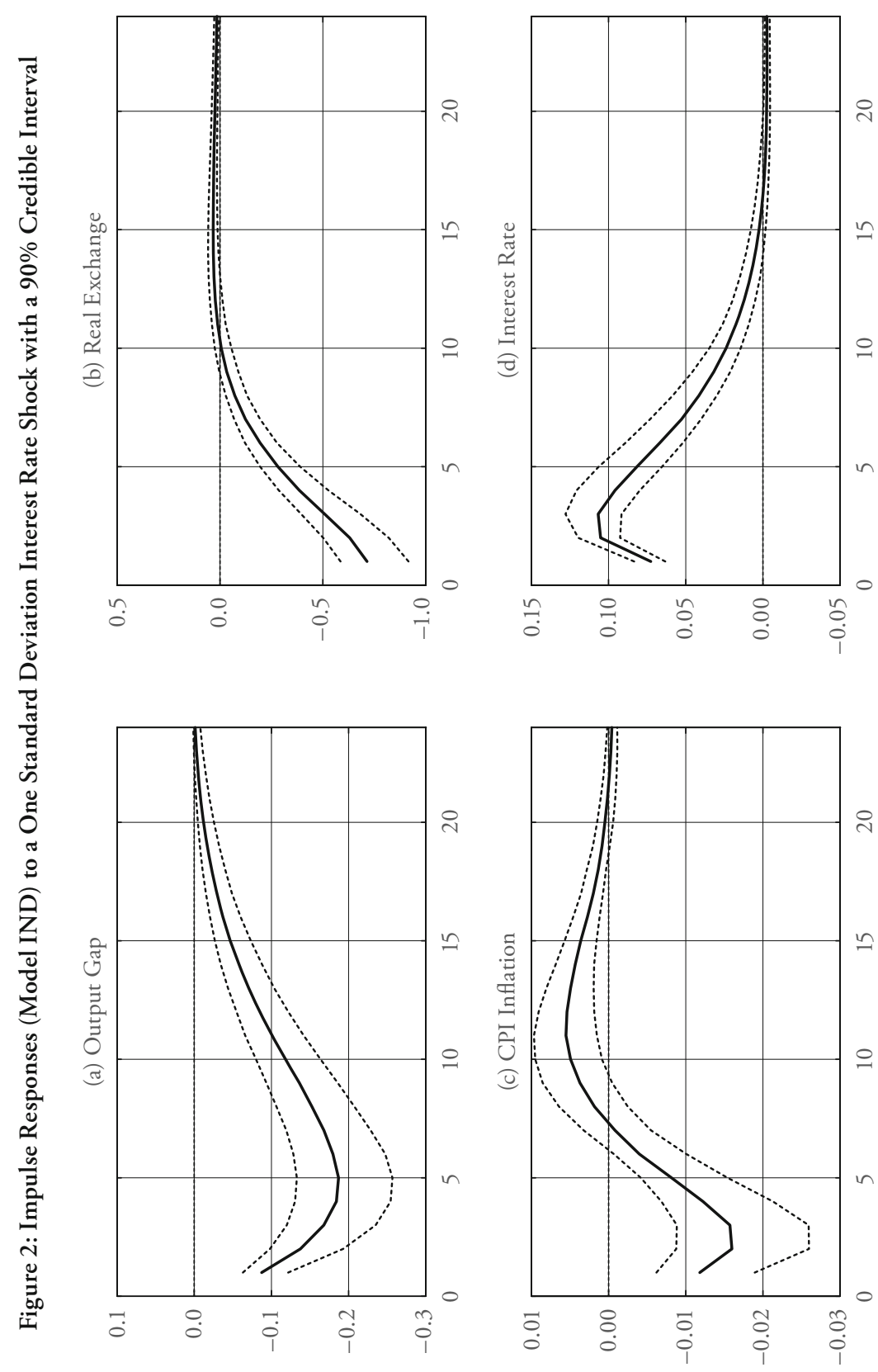

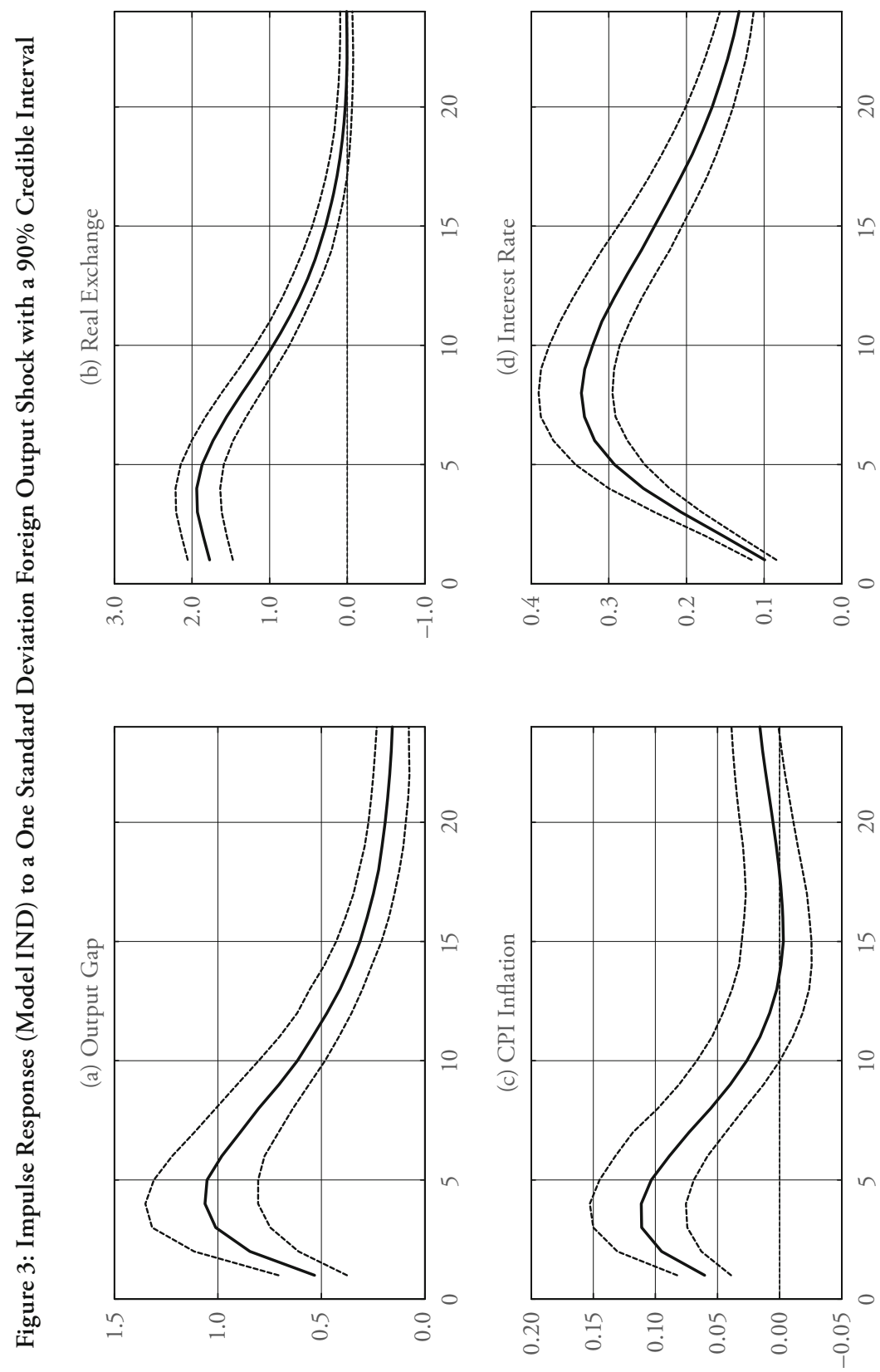

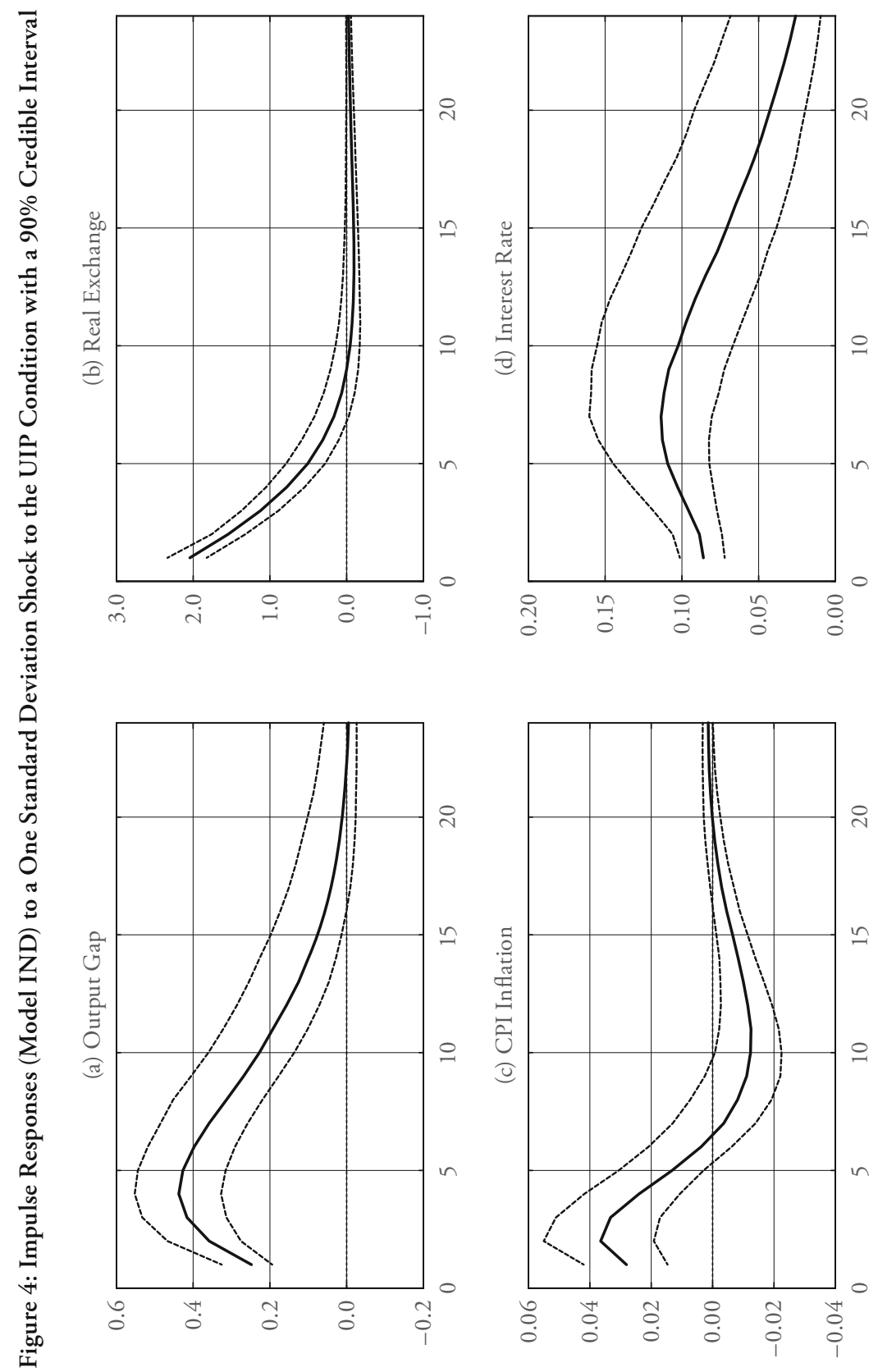
an increase of domestic output as the domestic economy can benefit from the depreciation of domestic currency. As natural output does not react to a UIP shock, the output gap moves one-to-one with output. Domestic inflation rises on impact but decreases afterwards, and the risk premium shock leads to a rise in the interest rate.

\section{Recessions and the Output Gap}

First, this section contrasts the model-based output gap measure to conventional measures of economic fluctuations such as the HP-cycle, detrended output ${ }^{19}$ and output growth. The main finding is that the model-based output gap measure is consistent with conventional measures as well with conventional wisdom about the performance of the Swiss economy. The advantage of the model-based output gap measure is that a shock decomposition can be performed, which is not possible for the other approaches. Second, the possibility for a shock decomposition is exploited, and the driving forces of the output gap are identified.

\subsection{Comparison of Measures of Economic Fluctuations}

Estimates of the output gap were obtained by running the Kalman smoother using the estimated posterior mean of the parameters. The best linear prediction of the states $X_{t}$ given the observations up to and including period $t$ is computed. Table 4 provides an overview on standard deviations of and correlations between different measures. The natural output gap as well as the detrended output is much more volatile than the HP-cycle or output growth. The high volatility of the natural output gap is consistent with output gap estimates for closed economies (Justiniano and Primiceri, 2008). Figures 5 to 7 compare the estimated model-based output gap to conventional measures of economic fluctuations such as the HP-cycle and the detrended GDP. Furthermore, different measures to determine recession periods are used in each plot.

19 Detrended GDP is the residual of the regression of the log of Swiss GDP on a constant and trend. 
Table 4: Standard Deviations of Output Gap Measures on the Diagonal, and Corresponding Correlations on the Off Diagonal

\begin{tabular}{lcccc}
\hline & $\tilde{y}$ & $\Delta y+z$ & $y$ & HP \\
\hline$\tilde{y}$ & 2.24 & & & \\
$\Delta y+z$ & 0.43 & 0.63 & & \\
$y$ & 0.77 & 0.23 & 3.07 & \\
HP-filter & 0.65 & 0.14 & 0.71 & 1.20 \\
\hline
\end{tabular}

Figure 5: Recessions Defined as two Consecutive Quarters of Negative Growth (Shaded Areas), Output Gap Estimate Based on Model IND

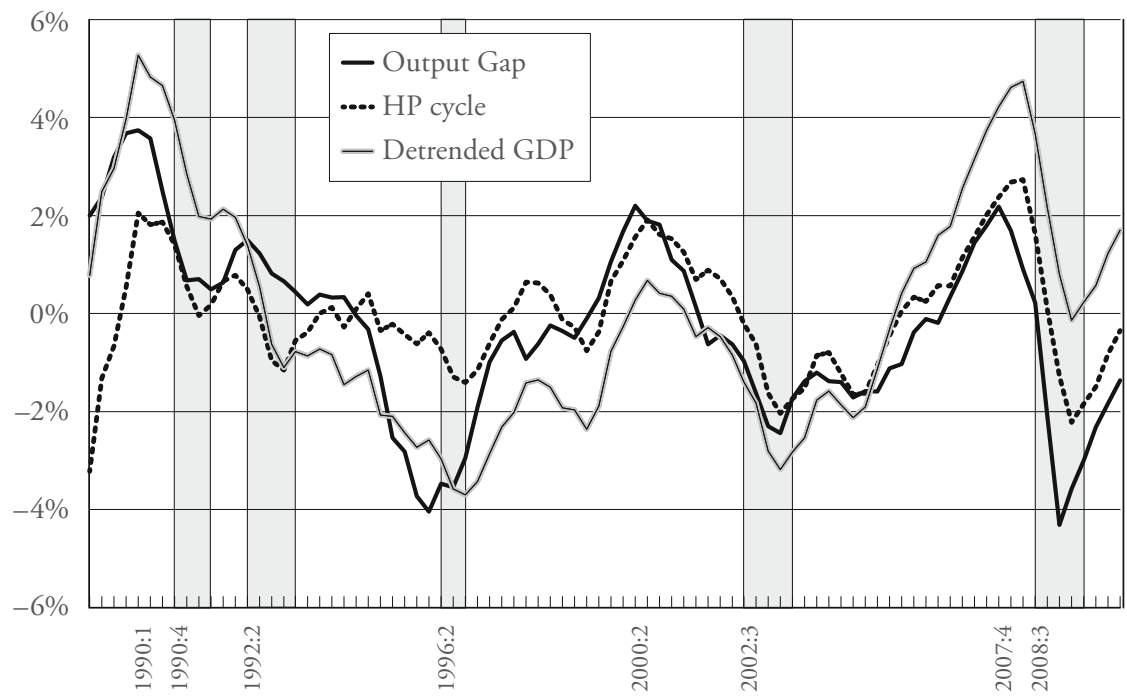

In Figure 5, recessions are plotted as shaded areas and are defined as two consecutive quarters with a negative growth rate. The first series depicted in Figure 5 is the estimated output gap using the best linear prediction based on the DSGE model. The other series are the business cycle derived from the Hodrick-Prescott (HP) filter and the detrended GDP. From this figure, we can infer that all series move in a comparable manner for most of the sample with the exception of the years 1995 to 1997, where the DSGE output gap series and detrended GDP deviate from its steady state up to more than $-4 \%$ while the HP-cycle closely 
fluctuates around zero. However, all series peak in 1990, 2001 and 2008 and exhibit a trough in 2003 and again at the end of 2008, which corresponds well to conventional wisdom. For a more thorough understanding, the following paragraphs exhibit a detailed discussion of the model-based series and the HP-cycle, and put them into an historical context.

The years 1989 and 1990 were characterized by a worldwide economic rebound and a domestic housing bubble. Therefore, where the SNB was mainly concerned about an appreciation of the domestic currency and a possibly vulnerable economy, their focus switched to the inflation pressure caused by the economic rebound in combination with a depreciation of the domestic currency (HiLdebRAND, 2004). Inflation increased up to 6.6\%, and the years 1991 to 1993, under conventional wisdom, were perceived as a recession (or at least stagnation). However, this does not conform to the estimated output gap. Although it sharply declines, the output gap stays positive.

It is interesting to note that the DSGE output gap depicts large negative values for the years 1995 to 1997. Although the economy was still weak and the structural crisis in the building and housing sector was still not completely eliminated, the SNB adhered to a tight monetary policy up until 1995. It was not until after the occurrence of the Mexican crisis and the following worldwide economic downturn that the SNB lowered interest rates, an action that was also due to the strong domestic currency and the stagnation of the domestic economy (HILDEBRAND, 2004). The negative values of the DSGE output gap correspond well with conventional wisdom that Switzerland faced stagnation, or at least weak growth, during the 1990s although there is some disagreement about the scale of this slowdown (Lambelet and Mihailov (1999), Kehoe and Ruhl (2005) and Abrahamsen et al. (2005)). However, this weak performance by the Swiss economy is captured only by DSGE output gap and detrended output; it is not captured by the HP-cycle. The large drop in the output gap coincides with the Mexican peso crisis (1995 to 1996).

Also in accordance with conventional wisdom, the HP-cycle, detrended output and DSGE output gap peak in 2001 after the burst of the technology bubble at the stock exchanges and before the terrorist attacks in the U.S.. According to all measures, the economy began to rebound in 2003 and the following boom peaked in 2008, when the financial crisis occurred. The dating of the downturn as well as the severity compared to other recessions is consistent with conventional wisdom. 
Figure 6: Low Growth Periods of the Markov-Switching Model with Two Regimes Siliverstovs (2011) (Shaded Areas) Compared to Model-Based Output Gap (IND)

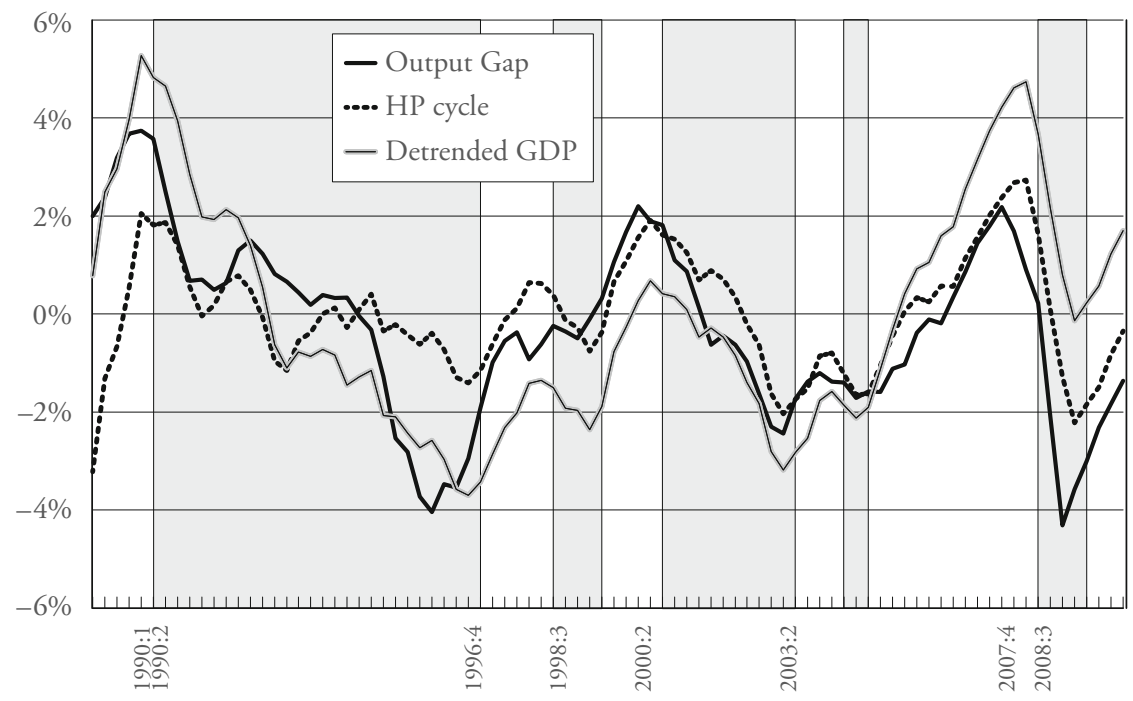

In Figure 6, the shaded areas correspond to the low-growth regime from a Markov-switching model that allows for only two regimes. The dating is taken from Siliverstovs (2011). All periods of low-growth correspond to downturns in both business cycle measures.

Figure 7 provides information on peaks and troughs if the same dating mechanism as for the US is applied to Swiss data. The information is provided by the Economic Cycle Research Institute (ECRI) ${ }^{20}$. The model-based output gap is also similar to these peak to trough periods. While the output gap begins to decline in the 1990:1 and reaches a trough in 1996:1, the ECRI turning point dates indicate a short upturn in the economy from 1993:3 to 1994:4. However, a recession then starts again and ends in 1996:3, only 2 quarters later than indicated by the model-based output gap. For the recession beginning around 2001 and for the great recession starting in 2008, both approaches yield similar recession dates up to a deviation of a few quarters.

20 www.businesscycle.com. 
Figure 7: Peak to Trough Periods Given by ECRI Shaded in Green

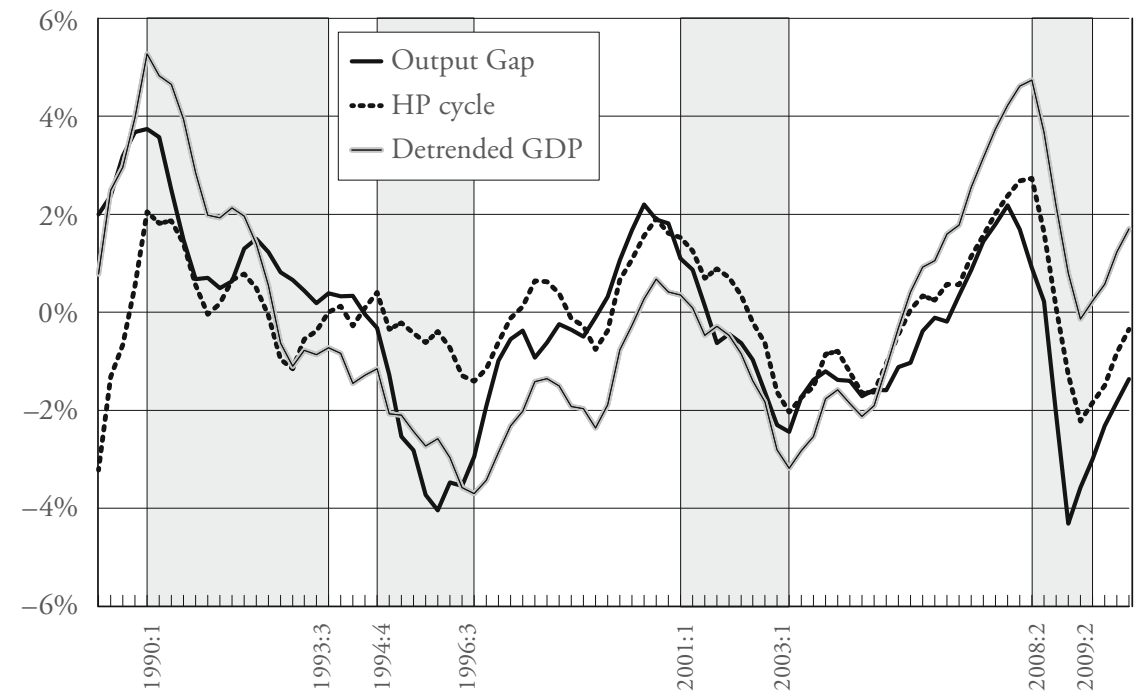

In light of the discussion in this section, we see that all measures perform similarly at measuring business cycles when comparing the estimated series to recession definitions. However, especially for the mid-1990s the DSGE output gap series seems to outperform the HP-cycle estimate. Therefore, it seems reasonable to conclude that the output gap measure derived from the DSGE model provides an alternative estimate of the business cycle. Furthermore, the DSGEbased output gap estimate can be used to analyze the recessions regarding their driving forces; this cannot be done when using agnostic statistical procedures. This advantage of the DSGE-based measure will be exploited in the next section.

\subsubsection{Shock Decomposition}

The series of output and the output gap are decomposed into historical shock contributions to analyze the Swiss business cycles. The historical shock decomposition was computed by switching off all but one of the shocks. Eight series for each measure corresponding to the evolution of the output gap given the realization of only one historical shock series were computed. These series were aggregated for each quarter and measure and the five most important shocks, in terms of their contribution to the output gap, were plotted as a stacked bar graph. 
Furthermore, the effect of initial values is neglected. Therefore, the bars do not add up to the plotted line corresponding to the smoothed series with respect to all shocks. However, the effect of initial values vanishes rather quickly and is not of interest and the contribution of the three minor shocks is negligible.

Figure 8 shows the decomposed DSGE output series. In the beginning of the 1990 s, the domestic inflation rate was high compared to the rest of the sample, and domestic inflation shocks had a considerable negative impact on output, which corresponds well to the historical account on the Swiss economy in chapter 5. Moreover, some regularities are worth mentioning. If the output series deviates at least $1.5 \%$ from the steady state, the shock to foreign output $\varepsilon_{y^{*}}$ acted procyclically. Furthermore, the contribution of the UIP shock also acted procyclically in boom and recession periods with only one exception. Remarkably, this exception occurred during the great recession, which had its roots in a financial crisis. This finding will be discussed below.

The shock decomposition of natural output will not be discussed in detail as it does react only to foreign variables and domestic productivity. Domestic natural output reacts to foreign interest rates and foreign inflation as the foreign economy is approximated by a VAR and the foreign output level $y^{*}$ is used to approximate $y^{* f f e x}$ and $z^{*} .^{21}$ The above-mentioned procyclical effect of the UIP shock is even more pronounced with respect to the output gap. However, Figure 9 shows also that this procyclical effect of the UIP shock breaks down in the latest recession. Interestingly, although foreign output had a positive effect on the output gap for almost every quarter over the years 2002 to 2006, the output gap remained negative during these years. This is not only due to the procyclical effect of the UIP shock but also to the huge negative effect of foreign interest rate shocks for the whole first decade of this century. This pronounced negative effect of foreign interest rates on the output gap stems from the negative effect on output itself, while natural output was positively affected during this period.

Figure 10 shows the evolution of the UIP shock $\left(\varepsilon_{q}\right)$, the real exchange rate, the interest rate and the output gap. We see that recession 1 (1994:3 to 1999:2) and recession 2 (2001:4 to 2006:1) showed a similar behavior. However, this holds only for the real exchange rate when we consider the last recession. In contrast,

21 The results presented herein do not depend on this. They still hold when using the structurally defined output gap as given in the appendix of the older version of this paper but defining $z^{*}=b_{11} \cdot \varepsilon_{y^{*}}$ (or $z_{t}^{*}=\rho_{z^{*}} z_{t-1}^{*}+\varepsilon_{y^{*}}$ ), where $\varepsilon_{y^{*}}$ is the identified structural shock from the VAR. In addition to the structural definition of the output gap, the equation defining foreign natural output is also implemented in these approaches. However, while the results stay qualitatively the same, the log marginal density indicates that these specifications are unlikely. 

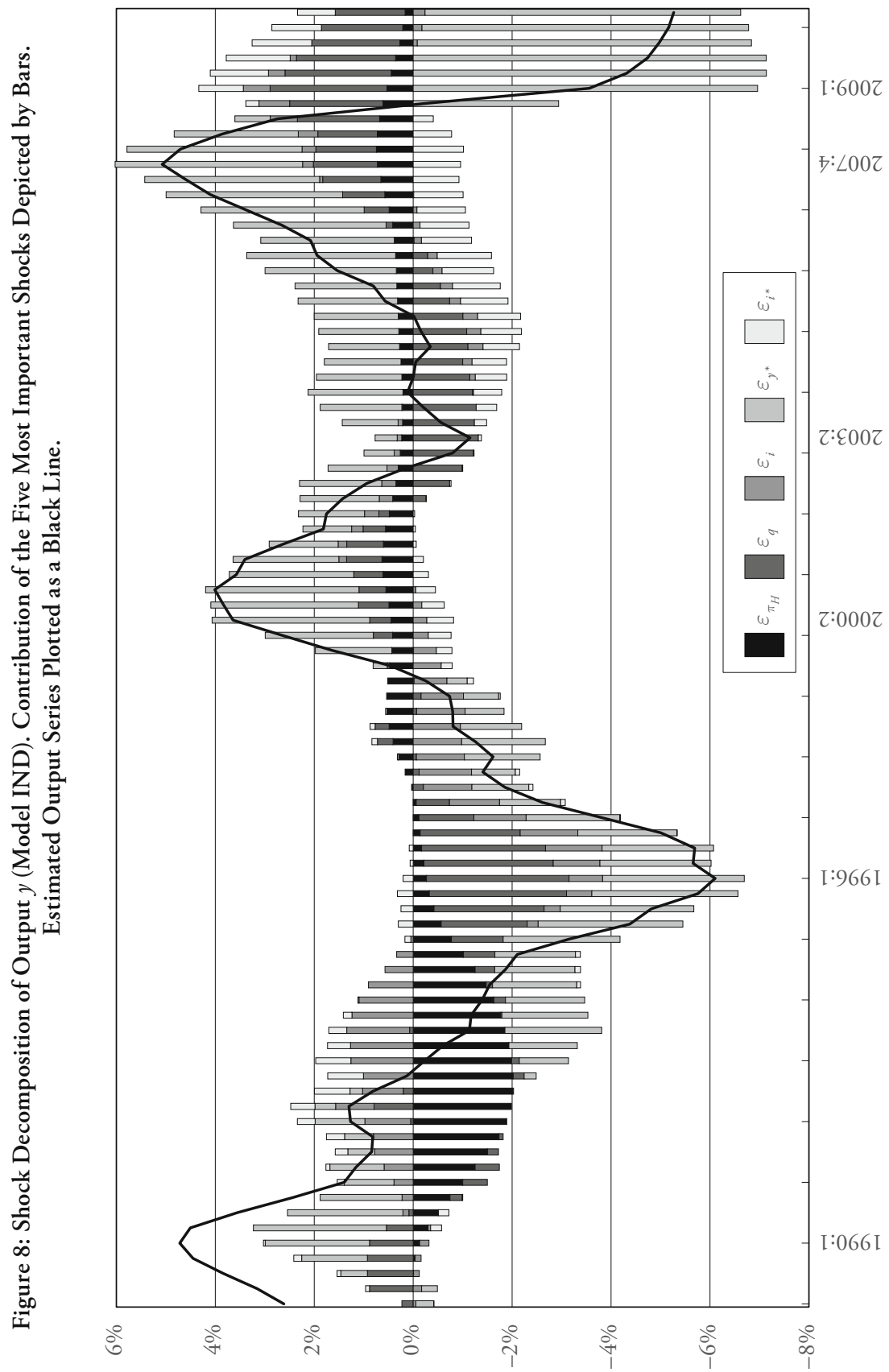

Swiss Journal of Economics and Statistics, 2013, Vol. 149 (4) 


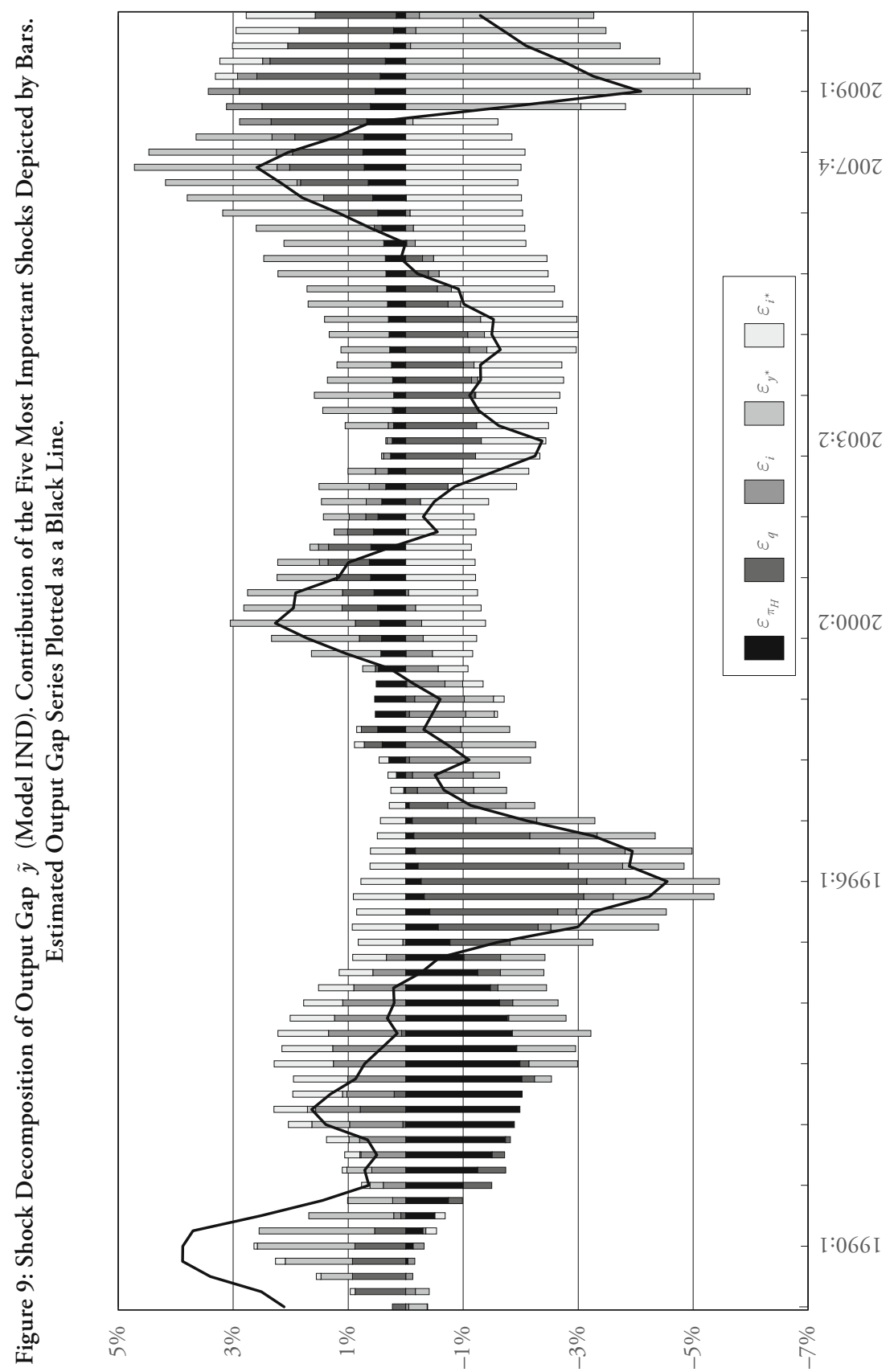

Swiss Journal of Economics and Statistics, 2013, Vol. 149 (4) 


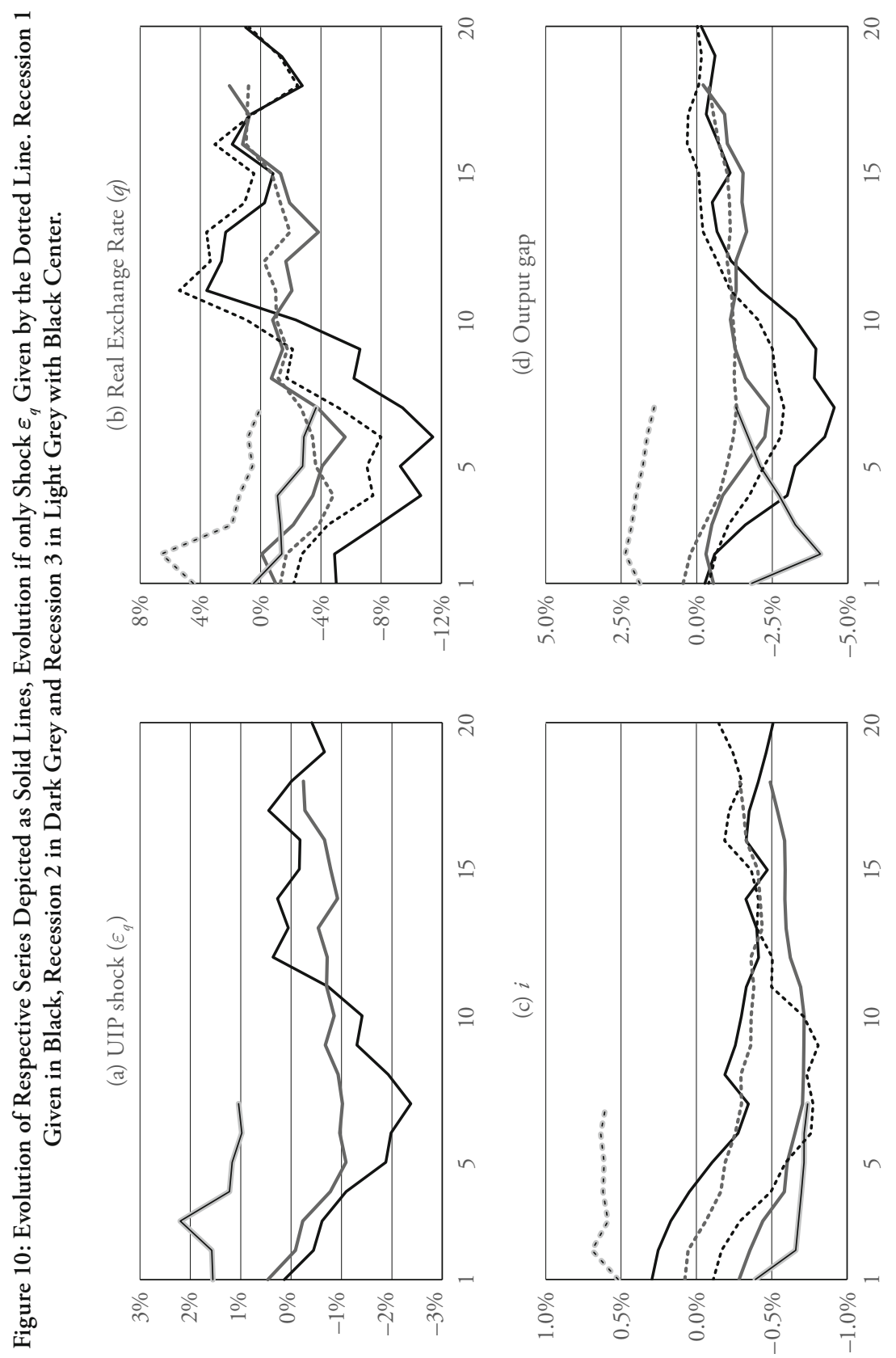



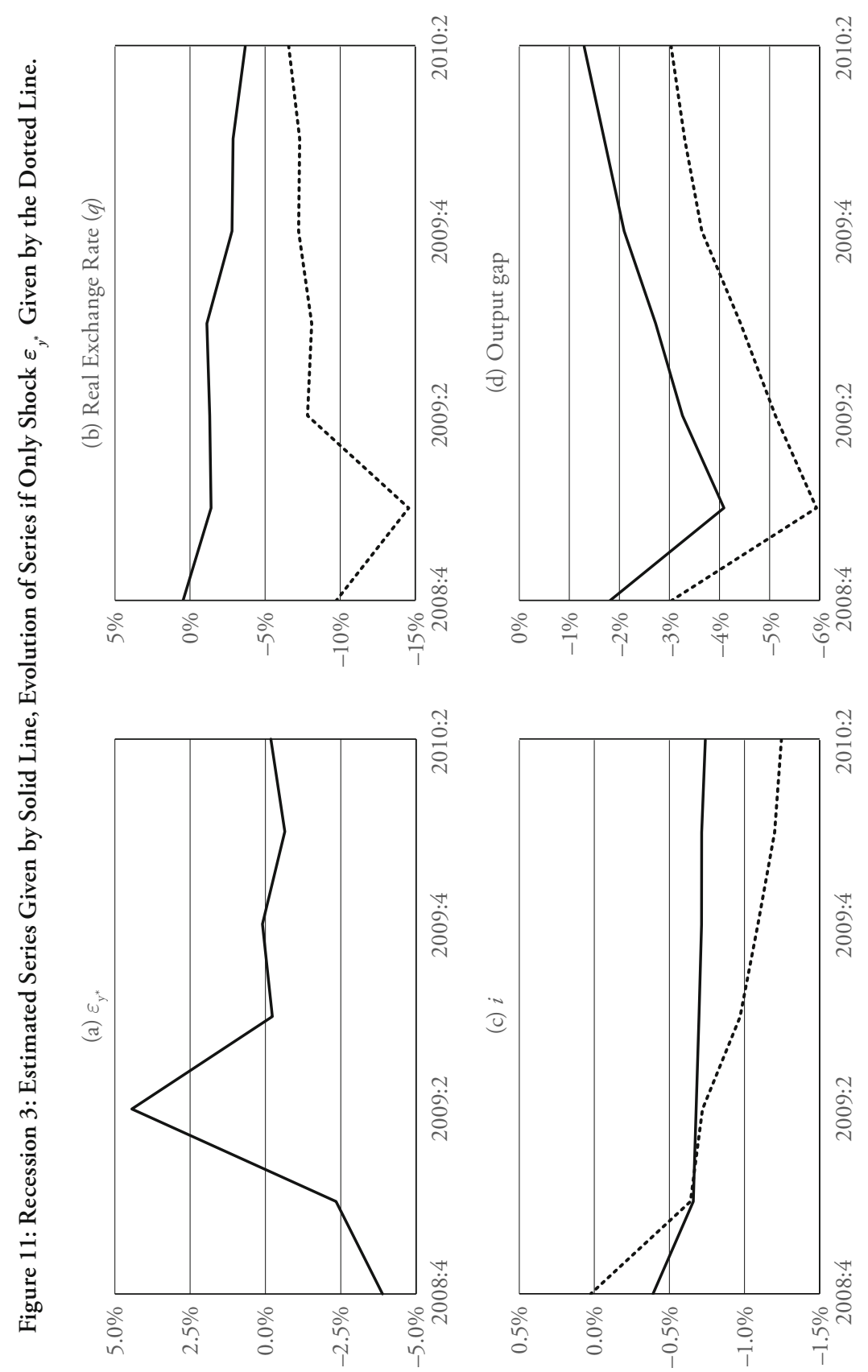
the behavior of the interest rate and output gap is different compared to the other recessions. Interest rates as well as the output gap would have been positive if only the UIP shock occurred and all other shocks had been zero. This is due to the positive UIP shock that led to an increase in the real exchange rate (depreciation of domestic currency), which would have been beneficial for the domestic output, in which case no recession had occurred. However, the effect of $\varepsilon_{q}$ was overwhelmed by the effect of the foreign output shock as stated in Table 5 and as also visible in Figure 11.

Tables 5 and 6 confirm the important role of the UIP and the foreign output shocks for the output gap. In Table 5, we see that the output gap was positively correlated with itself if only the UIP shock occurred for the whole sample as well as for the first two recession periods. However, this positive correlation breaks down during the last recession. This is also the case for the interest rate, but not the case for the real exchange rate. This change in correlation is mainly due to the increased contribution of the foreign output shock during the last recession. Finally, in Table 6, we see that while the UIP shock only affects the output gap in the very short run, the foreign output shock is the main component in the forecast error variance decomposition.

Table 5: Conditional Correlations of Respective Series with Series if Only One Specific Shock Occurred. Shocks Contribution to Series in Brackets.

\begin{tabular}{lcccc}
\hline shock & whole & $1994: 3$ & $2001: 4$ & $2008: 4$ \\
& sample & $1999: 2$ & $2006: 1$ & $2010: 2$ \\
\hline $\operatorname{corr}\left(\tilde{y}(\varepsilon), \tilde{y}\left(\varepsilon_{q}\right)\right)$ & 0.50 & 0.97 & 0.80 & -0.95 \\
& $(18 \%)$ & $(21 \%)$ & $(22 \%)$ & $(22 \%)$ \\
$\operatorname{corr}\left(\tilde{y}(\varepsilon), \tilde{y}\left(\varepsilon_{y^{*}}\right)\right)$ & 0.63 & 0.74 & 0.40 & 0.99 \\
& $(26 \%)$ & $(24 \%)$ & $(20 \%)$ & $(46 \%)$ \\
$\operatorname{corr}\left(q(\varepsilon), q\left(\varepsilon_{q}\right)\right)$ & 0.81 & 0.96 & 0.81 & 0.68 \\
$\operatorname{corr}\left(i(\varepsilon), i\left(\varepsilon_{q}\right)\right)$ & $(25 \%)$ & $(32 \%)$ & $(30 \%)$ & $(9 \%)$ \\
$\operatorname{mean}$ of $\varepsilon_{q}$ & 0.24 & 0.18 & 0.78 & -0.66 \\
& $(15 \%)$ & $(22 \%)$ & $(17 \%)$ & $(25 \%)$ \\
\hline
\end{tabular}


Table 6: Forecast Error Variance Decomposition of Output Gap (Model IND) for a Selection of Horizons (h). Shock Contributions Given in Percent.

\begin{tabular}{rcccccccc}
\hline h/shock & $\varepsilon_{\pi_{H}}$ & $\varepsilon_{\pi_{F}}$ & $\varepsilon_{q}$ & $\varepsilon_{i}$ & $\varepsilon_{z}$ & $\varepsilon_{y^{*}}$ & $\varepsilon_{\pi^{*}}$ & $\varepsilon_{i^{*}}$ \\
\hline 1 & 0.01 & 0.01 & 26.66 & 0.36 & 0.69 & 61.12 & 0.45 & 10.72 \\
4 & 0.31 & 0.14 & 6.41 & 0.53 & 0.47 & 80.65 & 1.17 & 10.33 \\
8 & 1.14 & 0.32 & 3.67 & 0.67 & 0.34 & 80.26 & 0.81 & 12.79 \\
12 & 1.87 & 0.40 & 3.12 & 0.70 & 0.29 & 76.20 & 1.23 & 16.20 \\
16 & 2.17 & 0.42 & 2.93 & 0.68 & 0.27 & 72.90 & 1.75 & 18.88 \\
20 & 2.21 & 0.41 & 2.84 & 0.66 & 0.27 & 70.85 & 1.98 & 20.78 \\
\hline
\end{tabular}

\section{Conclusion}

Most of the literature relies on pure statistical approaches to estimate the output gap. The drawback to such approaches is that these estimates are not based on economic theory. Thus, estimates based on agnostic statistical approaches do not provide the possibility to analyze the source of the variation in the output gap. Moreover, this estimate will be prone to the Lucas critique.

This paper describes the estimation of the output gap based on a New Keynesian small open economy model. This approach has the advantage that it relies on a microeconomic foundation and provides a clear definition of the output gap. The DSGE model exhibits imperfect competition in product markets and sticky prices. Compared to Leist and Neusser (2010), a richer framework was chosen such that external habit persistence is appropriately incorporated and deviations from the LOP are allowed. This leads to a more sophisticated specification of the flexible price output, which now depends not only on foreign output but also on domestic productivity and terms of trade under flexible prices. Using the output gap in the Taylor rule dominates models where output growth or detrended output is used in the Taylor rule. Hence, the output gap measure improves the model fit compared to just using GDP growth or detrended output, which is in contrast to the finding of Adolfson et al. (2008). Furthermore, adding the exchange rate to the Taylor rule and allowing for indexation in the NKPC improves the model fit.

The estimation results of the model with the output gap and exchange rate in the Taylor rule as well as the indexation in the NKPC suggest that output would have evolved differently in the absence of price rigidities. In the case of 
Switzerland, the difference between deviation of output from its steady state and deviation of natural output from its steady state lies in the range of approximately $\pm 4 \%$. Booms as well as recessions would have been less pronounced under flexible prices. Furthermore, the estimated output gap corresponds to conventional wisdom about Swiss business cycles and evolves similarly to detrended output and the HP-cycle. Moreover, it is also partially consistent with some agnostic definitions of recessions resulting from a regime switching model or from simply defining a recession as two quarters of negative growth rates in a row.

In contrast to agnostic approaches, the microeconomic foundation of the output gap estimation allows a detailed analysis of recessions. The first insight we gain from the shock decomposition is that the output gap is mainly driven by the UIP shock and foreign output shock. The latter finding is in contrast to Justiniano and Preston (2010a), who find that US disturbances have nearly no effect on Canada and conclude that this contrasts with other empirical work. Therefore, they suggest concentrating on international transmission mechanisms to improve in this dimension. The main difference to their approach lies in the use of a VAR model to approximate the foreign economy rather than using a DSGE model to characterize the foreign economy. Second, particularly interesting is the finding that the UIP shock acted procyclically with respect to the output gap over almost the whole sample, with the notable exception of the last recession. Therefore, the effect of the increased uncertainty about the large financial sector in Switzerland is reflected in this break-up of the co-movement of the output gap and the UIP shock. The increased uncertainty actually helped the Swiss economy as it led to a depreciation of the real exchange rate. Policy makers rely on such measures of the output gap and respond to shocks to the output gap. As this paper shows, the contribution of different shocks to the output gap changed over time. This should be taken into account by policy makers.

To gather more information regarding the interpretation of the UIP shock, we could include a financial sector into the model to discriminate between liquidity shocks and pure risk premium shocks. Furthermore, instead of approximating the foreign economy by a VAR, we could use a large-scale closed economy model for the foreign economy to make the domestic flexible price output dependent on the foreign flexible price output and foreign productivity shocks. 


\section{References}

Abrahamsen, Y., R. Aeppli, E. Atukeren, M. Graff, C. Müller, and B. Schips (2005), "The Swiss Disease: Facts and Artefacts. A Reply to Kehoe and Prescott", Review of Economic Dynamics, 8(3), pp.749-758.

Adjemian, Stéphane, Houtan Bastani, Michel Juillard, Ferhat Minoubi, George Perendia, Marco Ratto, and Sébastien Villemot (2012), "Dynare: Reference Manual, Version 4", Dynare Working Papers 1, CEPREMAP.

Adolfson, Malin, Stefan lasen, Jesper Lind, and Lars E. O. Svensson (2011), "Optimal Monetary Policy in an Operational MediumSized DSGE Model", Journal of Money, Credit and Banking, 43(7), pp. 1287-1331.

Adolfson, Malin, Stefan Lasen, Jesper Lind, and Mattias Villani (2007),

"Bayesian Estimation of an Open Economy DSGE Model with Incomplete Pass-Through", Journal of International Economics, 72(2), pp. 481-511.

Adolfson, Malin, Stefan Lasen, Jesper Lind, and Mattias Villani (2008), "Evaluating an Estimated New Keynesian Small Open Economy Model", Journal of Economic Dynamics and Control, 32(8), pp. 2690-2721.

An, Sungbae, and Frank Schorfheide (2007), "Bayesian Analysis of DSGE Models", Econometric Reviews, 26(2-4), pp. 113-172.

Andres, Javier, J. David Lopez-Salido, and Edward Nelson (2005), "StickyPrice Models and the Natural Rate Hypothesis", Journal of Monetary Economics, 52(5), pp. 1025-1053.

Bachmann, Andreas (2012), "Exchange Rate Pass-Through to Various Price Indices: Empirical Estimation Using Vector Error Correction Models", Diskussionsschriften dp1205, Universität Bern, Departement Volkswirtschaft.

Bäurle, Gregor, and Tobias Menz (2008), "Monetary Policy in a Small Open Economy Model: A DSGE-VAR Approach for Switzerland", Working Papers 08.03, Swiss National Bank, Study Center Gerzensee.

Beltran, Daniel O., and David Draper (2008), "Estimating the Parameters of a Small Open Economy DSGE Model: Identifiability and Inferential Validity", International Finance Discussion Paper 955, Board of Governors of the Federal Reserve System.

Campa, José Manuel, and Linda S. Goldberg (2005), "Exchange Rate PassThrough into Import Prices", The Review of Economics and Statistics, 87(4), pp. 679-690.

Chari, V. V., Patrick J. Kehoe, and Ellen R. McGrattan (2002), "Can Sticky Price Models Generate Volatile and Persistent Real Exchange Rates?”, Review of Economic Studies, 69(3), 533-563. 
Christiano, Lawrence J., Martin Eichenbaum, and Charles L. Evans (2005), "Nominal Rigidities and the Dynamic Effects of a Shock to Monetary Policy”, Journal of Political Economy, 113(1), pp. 1-45.

Clarida, Richard, Jordi Gali, and Mark Gertler (1998), "Monetary Policy Rules in Practice: Some International Evidence”, European Economic Review, 42(6), 1033-1067.

Corsetti, Giancarlo, and Paolo Pesenti (2005), "International Dimensions of Optimal Monetary Policy", Journal of Monetary Economics, 52(2), pp. 281-305.

Del Negro, Marco, and Frank Schorfheide (2009), "Inflation Dynamics in a Small Open Economy Model under Inflation Targeting: Some Evidence from Chile", in Monetary Policy under Uncertainty and Learning, Klaus Schmidt-Hebbel, Carl E. Walsh, Norman Loayza, and Klaus Schmidt-Hebbel, eds., vol. 13 of Central Banking, Analysis, and Economic Policies Book Series, chap. 13, pp. 511-562, Central Bank of Chile.

Edge, Rochelle M., Michael T. Kiley, and Jean-Philippe Laforte (2008), "Natural Rate Measures in an Estimated DSGE Model of the U.S. Economy", Journal of Economic Dynamics and Control, 32, pp. 2512-2535.

Fagan, Gabriel, Jérôme Henry, and Ricardo Mestre (2001), "An AreaWide Model (AWM) for the Euro Area”, Working Paper Series 42, European Central Bank.

Fernández-Villaverde, Jesús (2009), "The Econometrics of DSGE Models", NBER Working Papers 14677, National Bureau of Economic Research, Inc. Fuhrer, Jefrrey C. (2000), "Habit Formation in Consumption and Its Implications for Monetary-Policy Models", American Economic Review, 90(3), pp. 367-390.

Galí, Jordi (2008), Monetary Policy, Inflation, and the Business Cycle: An Introduction to the New Keynesian Framework, Princeton University Press.

Galí, Jordi, and Tommaso Monacelli (2005), "Monetary Policy and Exchange Rate Volatility in a Small Open Economy", Review of Economic Studies, 72, pp. 707-734.

Geweke, John (1999), "Using Simulation Methods for Bayesian Econometric Models: Inference, Development, and Communication”, Econometric Reviews, 18(1), pp. 1-73.

Hildebrand, Philipp M. (2004), „Vom Monetarismus zur Inflationsprognose: Dreissig Jahre Schweizerische Geldpolitik“, Öffentliche Vorlesung Universität Bern.

Hooper, Peter, Karen Johnson, and Jaime Marquez (1998), "Trade Elasticities for G-7 Countries", International Finance Discussion Papers 609, Board of Governors of the Federal Reserve System (U.S.). 
Justiniano, Alejandro, and Bruce Preston (2010a), "Can Structural Small Open-Economy Models Account for the Influence of Foreign Disturbances?", Journal of International Economics.

Justiniano, Alejandro, and Bruce Preston (2010b), "Monetary Policy and Uncertainty in an Empirical Small Open Economy Model”, Journal of Applied Econometrics, 25, pp. 93-128.

Justiniano, Alejandro and Giorgio Primiceri (2008), "Potential and Natural Output".

Kass, R. E., and A. E. Raftery (1995), "Bayes Factors", Journal of the American Statistical Association, pp.773-795.

Kaufmann, Daniel (2009), "Price-Setting Behaviour in Switzerland: Evidence from CPI Micro Data", Swiss Journal of Economics and Statistics (SJES), 145(III), pp. 293-349.

Kenoe, Timothy J., and Kim J. Ruhl (2005), "Is Switzerland in a Great Depression?”, Review of Economic Dynamics, 8(3), pp.759-775.

Kydland, Finn E., and Edward C. Prescott (1982), "Time to Build and Aggregate Fluctuations", Econometrica, 50(6), pp. 1345-1370.

Lambelet, Jean-Christian, and Alexander Mihailov (1999), "A Note on Switzerlands Economy: Did the Swiss Economy Really Stagnate in the 1990s, and Is Switzerland All That Rich?”, Tech. rep., Créa Institute, Lausanne University.

Leist, Stefan (2011), "Driving Forces of the Swiss Output Gap”, Diskussionsschriften dp1107, Universität Bern, Departement Volkswirtschaft.

Leist, Stefan, and Klaus Neusser (2010), "Measuring the Natural Output Level by DSGE Models: An Empirical Investigation for Switzerland", Swiss Journal of Economics and Statistics (SJES), 146(I), pp. 275-300.

Lubik, Thomas, and Frank Schorfheide (2006), "A Bayesian Look at New Open Economy Macroeconomics", in NBER Macroeconomics Annual 2005, Mark Gertler and Kenneth Rogoff, eds., vol.20, pp.313-366, Cambridge, Massachusetts: MIT Press.

Lubik, Thomas A., and Frank Schorfheide (2007), "Do Central Banks Respond to Exchange Rate Movements? A Structural Investigation", Journal of Monetary Economics, 54, pp. 1069-1087.

McCallum, Bennett T. (2001), "Should Monetary Policy Respond Strongly to Output Gaps?”, American Economic Review, 91(2), pp. 258-262.

McCallum, Bennett T., and Edward Nelson (1999), "Performance of Operational Policy Rules in an Estimated Semiclassical Structural Model", in Monetary Policy Rules, NBER Chapters, pp. 15-56, National Bureau of Economic Research, Inc. 
Monacelli, Tommaso (2005), "Monetary Policy in a Low Pass-Through Environment.", Journal of Money, Credit \& Banking, 37(6), pp. 1047-1066.

Neiss, Katharine S., and Edward Nelson (2005), "Inflation Dynamics, Marginal Cost, and the Output Gap: Evidence from Three Countries", Journal of Money, Credit \& Banking, 37(6), pp. 1019-1045.

Rabanal, Pau, and Juan F. Rubio-Ramirez (2005), "Comparing New Keynesian Models of the Business Cycle: A Bayesian Approach", Journal of Monetary Economics, 52(6), pp. 1151-1166.

Rudolf, Barbara, and Mathias Zurlinden (2011), „Potenzialoutput und Outputlücke aus geldpolitischer Sicht“, Die Volkswirtschaft, 6.

Siliverstovs, Boriss (2011), "Dating Business Cycles in a Historical Perspective: Evidence for Switzerland”, KOF Working papers 11-284, KOF Swiss Economic Institute, ETH Zurich.

Stalder, Peter (2002), "The Changing Role of Foreign Labor and Female Participation: Impacts on Wage-Price Dynamics and Unemployment in Switzerland", Mimeo.

TaYlor, John (1993), Macroeconomic Policy in a World Economy: from Economic Design to Practical Operation, W. W. Norton.

Woodford, Michael (2003), Interest and Prices: Foundations of a Theory of Monetary Policy, Princeton University Press.

\section{SUMMARY}

What drives the output gap? Contrary to standard agnostic statistical approaches, New Keynesian small open economy models allow decomposing the output gap into its shocks and confirm the conventional wisdom that most of the variation is due to foreign shocks. However, the risk premium shock also plays an important role. It has a procyclical effect on the output gap except for the most recent recession, where the economic agents demanded a higher risk premium probably due to the large Swiss financial sector. This helped to dampen the recession because of the depreciation of the domestic currency due to this shock. 